\title{
CONTRACT RIGHTS AS COMMERCIAL SECURITY: PRESENT AND FUTURE INTANGIBLES
}

Forming as they do a significant element of national wealth, intangibles present an important resource for secured financing. ${ }^{1}$ Courts and legislatures, however, have appeared hesitant in according validity to intangible security and have questioned its desirability in commercial financing. ${ }^{2}$ Nevertheless, all existing security devices, from the chattel mortgage to the trust receipt,

1. Traditionally, security for a loan was taken in real property in the form of a real estate mortgage. GLENN, MortGages $\$ \S 1,2$ (1943). Tangible personalty became utilized as a basis for security in devices developed by analogy to the real estate mortgage. Gilmore \& Axelrod, Chattel Security I, 57 Y financing has been based on intangibles, which represent an increasing proportion of national wealth. The term intangible includes both choses in action, i.e., claims based on legal rights, and such assets as are considered intangible property for accounting purposes. See Commitiee on Accounting Prockdure, American Institute of AccountANts, Accounting for Intangible Assets (Accounting Research Bull. No. 24, Dec. 1944); 1 Glenn, Fraudulent Conveyances and Preferences $\$ 144$ (rev. ed. 1940) (hereinafter cited as GLENN). Some types of intangible property particularly well adapted for this purpose are patents, copyrights, leases, licenses and secret processes. However, the most widely used form of intangible collateral is a chose in action, the account receivable. Cohen \& Gerber, Mortgages of Accounts Receivable, 29 Geo. L.J. 555 (1941); Koessler, Assignment of Acconnts Receivable, 33 CALIF. L. Rev. 40 (1945). And many contract rights which do not take the form of open book accounts, and hence are not usually denominated accounts receivable, see notes 98, 99 infra, are also employed, see Costello v. Bank of America Nat'l Trust \& Sav. Ass'n, 246 F.2d 807 (9th Cir. 1957) (assigned right which was not an open book account held not an account receivable within the meaning of CAL. Crv. CoDE $\$ 3017$ ).

2. Distrust of the expansion of credit based on such financing is seen in Corn Exchange Nat"l Bank \& Trust Co. v. Klauder, 318 U.S. 434 (1943), and in congressional dislike for the lack of notoriety inherent in the use of intangibles as security evidenced by the development of $\S 60$ of the Bankruptcy Act, 52 STAT. 869 (1938), as amended, 11 U.S.C. $\$ 96$ (1952). Oglebay, Proposed Revision of Section 60a of the Bankruptcy Act: A Step Backward, 51 Cox. L.J. 263 (1947). The process of expansion is described in Gilmore, The Sccured Transactions Article of the Commercial Code, 16 LAW \& Contexp. ProB. 27, 29 (1951): "It is in the provision of working capital for small and medium-sized businesses and in the distribution of durable goods to consumers that secured lending has sprung up in a wild and rank profusion of short-term security devices: chattel mortgage; conditional sale; bailment-lease; trust receipt; factor's lien; possessory and non-possessory; assignment of accounts receivable; field warehousing; plus a variety of futuristic forms just beginning to be experimented with. ...

"Short-term security devices have multiplied because lending agencies have progressively lowered the barriers which once made it impossible for the marginal borrower to get bank money. The greater credit risk is sought to be mitigated by always taking security. The new borrower, however, cannot offer the traditional types of collateral: real estate, industrial equipment, or securities to be left in pledge. The old devices have to be stretched, or new ones invented, to deal with the new collateral ...." For a presentation of the arguments in opposition to the expansion of secured financing, see id. at 36 . 
have overcome comparable opposition. ${ }^{3}$ And one form of intangible-the shortterm contract right or account receivable-is presently a recognized and institutional basis of secured lending. ${ }^{4}$ Viewed against this background, another intangible, the long-term contract right, seems destined to become an increasingly utilized security. ${ }^{5}$ The nature or stage of development of a business, or previous encumbrance of the assets which would ordinarily be used as collateral for loans, may often make such rights the best security a prospective borrower can offer. In these circumstances, a loan may be necessary to enable the borrower to perform or benefit from the contract. Thus, a uranium miner may desire to borrow periodically to meet payroll and operational expenses

3. Gilmore \& Axelrod, supra note 1, at 532; Note, 66 YALE L.J. 922 (1957).

4. Both notification lending - where the obligor on the underlying contract is informed of the assignment-and nonnotification lending on the basis of accounts receivable is extensively used in the United States. Silverman, Factoring of Accounts Receivable, 27 Harv. Bus. Rev. 594 (1949); Note, 24 N.Y.U.L.Q. Rev. 598 (1949); Note, 101 U. PA. L. REv. 392 (1952). Although use of nonnotification financing was threatened by the decision in Corn Exchange Nat'l Bank \& Trust Co. v. Klauder, 318 U.S. 434 (1943), the rapid response to that decision in the form of passage of validation or recordation statutes of various types by thirty-six states, making the validity of an assignment in no way dependent on notification, Comment, 67 Y ALE L.J. $402,410 \mathrm{nn} .31$ \& 33 (1958), preserved the device. In the majority of the states, the so-called English rule established in Dearle v. Hall, 3 Russ. 1 (Ch. 1823), whereby the first assignee to notify the obligor of his assignment prevails over any other assignee regardless of the actual order of assignment, was never accepted. Therefore nonnotification financing would, in such states, be unassailable by a subsequent assignee for value if the common law was applicable. The 1950 amendment of $\$ 60$ (a) of the Bankruptcy Act, by substituting a judicial lien creditor test for the 1938 bona fide purchaser test judging perfection of an assignment, makes passage of further validation statutes unnecessary to protect nonnotification assignment arrangements from avoidance under $\$ 60$ (a). 64 STAT. 24 (1950), 11 U.S.C. $\$ 96$ (1952). For in contrast to a bona fide purchaser, a judicial lien creditor may not generally obtain a greater right in property than a nonnotifying assignee. See note 39 infra.

5. A contract right is property. 4 CoRBIN, CONTRACTs $\S 860$ (1951) (hereinafter cited as CoRBIN); 1 GLENN §§ 137-39. An existing contract right is assignable if it need not be performed by, or to, the assignor personally. 4 CoRBIN $\S 865$. Legal duties cannot be assigned. "The performance required by a duty can often be delegated; but by such a delegation the duty itself is not escaped." 4 id. $\$ 866$. The assignor remains liable for performance which may have been delegated but which has not been rendered. "For purposes of assignment ... of performance, a contractor can separate his rights from his duties. (1) He can assign his rights to another and perform his duties himself; as where a teacher assigns his right to future salary and goes on teaching, or where a builder assigns his right to progress payments and proceeds with the work. (2) He can assign his rights to an assignee, and delegate performance of his duties to the assignee or to a third party if the performance is not of a personal character. (3) He can retain his rights, and at the same time employ a substitute to render the performance of his duties and conditions precedent." 4 id. \$ 867 .

Statutes may limit assignments, see Fortas, Wage Assignments in Chicago, 42 Yare L.J. 526 (1933), as well as specifically permit them, Note, 101 U. PA. L. REv. 106 (1951); 41 VA. L. REv. 984 (1955). And the terms of the contract under which the rights arise may seek to prevent assignment. See notes 53-57 infra and accompanying text. 
until he begins to market the ore; to assure repayment, he is willing to "pledge" his license to prospect for and excavate the mineral in a defined geographical area. Conversely, the underlying contract may be executory. ${ }^{6}$ Illustrative is the building contractor, about to enter into a long-term construction contract providing for progress payments, who desires to borrow on the security of a fixed amount of the payments. Alternatively, a manufacturer acquiring a ten-year requirement contract, whose property is encumbered by an industrial mortgage with an after-acquired property clause, may wish to utilize his rights under that contract to secure a loan enabling needed expansion of his operations. Despite the apparent value of the contract right, the borrower will encounter great difficulty in arranging for a secured loan based on this type of asset. In accounting terms, a valuable right arising under an as yet executory contract is not ordinarily stated as an asset of the business; such a right, if partly performed, is stated only to the extent of performance entitling payment. ${ }^{7}$ More important, a contract right is a very uncertain form of security from the legal viewpoint, even though the potential value of the contract can be appreciated at the time of its inception.

Nevertheless, contract rights have served as security in commercial arrangements. Included have been leases, ${ }^{8}$ licenses, ${ }^{9}$ construction ${ }^{10}$ and other long-

6. 4 CoRBIN $\$ \$ 67$.

A contract is entirely executory if no performance has been rendered under it. The typical account receivable arises from a contract which is wholly performed on one side, that of the borrower. The only performance due is that of the purchaser of goods, who must pay. Such performance is assignable for security.

A contract which is entirely unperformed, or which imposes a continuing obligation to perform as a condition precedent to payment, may also serve as the basis of an assignment. Rockmore v. Lehman, 129 F.2d 892 (2d Cir. 1942). And the assigned performance need not be of a money payment so long as the obligor's performance is not made unduly burdensome by the change in party to whom it must be rendered.

7. Paton, Essentials of Accounting 26 (1946): "On the other hand not all claims and rights, even where valuable in the general sense, rate as assets. In the case of contracts with respect to which there has been no performance by either party it is usually assumed that there is no asset to be recognized." See Herwitz, Accounting for Long-Term Construction Contracts: A Lawyer's Approach, 70 HARv. L. REv. 449, 455 (1957); Wagman, Tax Accounting For Long-Term Contracts, 33 TAxes 277, 279 (1955).

8. Camco Oil Corp. v. Vander Laan, 220 F.2d 897 (5th Cir. 1955) (assignment of undivided one-fourth interest in oil leases); Guinzburg v. D. A. Schulte, Inc., 91 F.2d 733 (2d Cir. 1937) (lessee assigned to lessor any and all subleases then or later to be made as security for performance of the lease); In re McCrory Stores Corp., 73 F.2d 270 (2d Cir. 1934) (same).

9. Licenses or franchises may represent a substantial intangible asset. Great American Indemnity Co. v. Allied Freightways, Inc., 325 Mass. 568, 91 N.E.2d 823 (1950) ("operating authority" capable of assignment); cf. In re Waterson Co., 48 F.2d 704 (2d Cir. 1931) (writer's royalty agreement with publisher); 1 GLENN $\S 144$.

10. McCluer v. Heim-Overly Realty Co., 71 F.2d 100 (8th Cir. 1934); In re Cincinnati Iron Store Co., 167 Fed. 486 (6th Cir. 1909); Allhusen v. Caristo Constr. Corp., 303 N.Y. 446,103 N.E.2d 891 (1952). 
term contracts, ${ }^{11}$ in addition to the more representative account receivable. ${ }^{12}$ The rights assigned have flowed from contracts requiring periodic performance by both contracting parties, thus securing periodic loans, ${ }^{13}$ and contracts demanding an initial or single large investment, hence protecting an individual loan which may be repaid from one or many future receipts of performance. ${ }^{14}$ Security may consist of either a partial ${ }^{15}$ or an entire assignment of rights

11. 4 CORBIN $\S 884$ discusses the assignability of various contractual rights and duties arising out of an output or requirement contract. Assignable under such contracts would be rights to payment and some reasonably fixed rights to performance. In Arkansas Valley Smelting Co. v. Belden Mining Co., 127 U.S. 379 (188S), a mining company contracted to sell its ore output to a sampling company which was to crush, sample, assay and pay for the ore. The sampling company assigned its rights under the contract. Its right to delivery and to pay was assignable, but its duty to assay was not. The assignee gained no enforceable rights since this was an outright assignment. An assignment for security of the right to delivery of the ore would have been valid if the assignor continued assaying the ore. See, e.g., British Waggon Co. v. Lea \& Co., 5 Q.B.D. 149 (1880); In re Talbot Canning Corp., 35 F. Supp. 680 (D. Md. 1940).

Illustrative of unique long-term contracts is the milk check assignment, an order signed by the debtor (farmer) directing the creamery to pay a fixed amount or percentage of the proceeds of milk deliveries to a named credit institution. The contract for delivery and purchase over a stated period is essential to the validity of the assignment, which is a simplified notification financing arrangement. O'Niel v. Wm. B. H. Kerr Co., 124 Wis. 234, 102 N.W. 573 (1905) ; cf. Malone v. Bolstein, 151 F. Supp. 544 (N.D.N.Y. 1956), aff'd, 244 F.2d 954 (2d Cir. 1957).

12. For description of accounts receivable as an institutional source of commercial credit, see Kripke, Current Assets Financing as a Source of Long-Term Capital, 36 Mrns. L. Rev. 506 (1952); Silverman, Factoring as a Financing Device, 27 Harv. Bus. Rev. 594 (1949); Note, 101 U. PA. L. Rev. 392 (1952).

13. Jamestown Veneer \& Plywood Corp. v. Andrews, 93 F.2d 989 (3d Cir. 1938) (assignment as security of accounts to arise out of manufacturer's contractual sales of furniture given to induce assignee to sell materials on credit); Peterman Lumber Co. v. Adams, 128 F. Supp. 6 (W.D. Ark. 1955); In re Berdick, 56 F.2d 288 (S.D.N.Y. 1931).

14. In re New York, N.H. \& H.R.R., 25 F. Supp. 874 (D. Conn. 1938) (large loan from RFC secured by the borrower's right to future periodic payments from its obligor); In re Italian Cook Oil Corp., 190 F.2d 994, 995 (3d Cir. 1951); In re Allied Products Co., 134 F.2d 725 (6th Cir. 1943) (assignment of moneys due and to become due on construction contract in return for obligation incurred by furnishing surety bond); Scarborough v. Berkshire Fine Spinning Associates, 128 F. Supp. 948 (S.D.N.Y. 1955) (assignment of proceeds of government contract in payment for conditional sale of cloth to be used in performance of the contract).

15. See New York Law Revision Commission, Assignment of Accounts ReCEIvABLe 353, 365 (1946) (hereinafter cited as Report), for a study of the legal development of the partial assignment. For the modern status of the partial assignment, see note $24 \mathrm{infra.}$. In the noncommercial context, the only policy reason for holding a partial assignment invalid at law is the possibility of exposing the obligor to a multiplicity of suits. Note, 30 Micr. L. REv. 1338, 1339 (1932). However, in the modern commercial context, partial assignments, while frequently desirable, may be thought to contribute to a dishonest assignor's opportunity to make a double assignment. As a rule, only a single finance company deals with a borrower. Notes, 66 YALE L.J. 922 (1957), 101 U. PA. L. Rev. 392, 393 (1952); cf. In re Cotton Manufacturers' Sales Co., 
arising under one or more contracts. ${ }^{18}$ Moreover, the terms of the assignment may allow the assignee an option to undertake the performance required of the assignor when necessary to completion of the underlying contract. ${ }^{17}$ Often, the most commercially desirable assignment contemplates subjection of the security to the assignee's interest only upon occurrence of a specified condition. ${ }^{18}$ Regardless of the variation of arrangements which may be dictated by business necessity, the diligent lender can obtain a valid security interest in a contract right if he guards against existing legal obstacles. Foremost among these obstacles are the basic doctrines of enforceability: to be fully effective, an assignment must be legal not equitable and involve present rather than future property.

\section{The Enforceable Assignment}

Historically, all assignments of choses in action were unenforceable on the theory of conflict with rules against champerty and maintenance or because the materialism of courts precluded recognition of a conceptual transfer

209 Fed. 629 (E.D. Pa. 1913). Therefore, this argument against legal validity for commercial partial assignments seems unwarranted. Moreover, other rules specifically directed to invalidating fraudulent transactions are better suited to deal with this problem. And, in most states, under interpleader statutes, the problem of multiplicity of suits can be avoided.

16. Under the typical accounts receivable financing arrangement, the borrower promises to assign all his accounts receivable, up to a specified sum, to the lender. Where no afteracquired property doctrine impedes, see note 26 infra, such an assignment will effectually transfer the accounts. Where such a doctrine prevails, each new account must be identified in a periodic statement of assigned accounts. And the practice of periodic identification may be employed universally for practical as well as legal reasons. Note, $101 \mathrm{U}$. PA. L. REv. 392, 393-94 (1952). Each assigned account represents the transfer of either express or implied-in-fact contractual obligations of the obligor to pay for goods received. In the accounts receivable field, many contracts may have to be assigned, with concomitant increase in credit risk to the lender and, therefore, in financing charges. But in the case of a borrower possessing a long-term contract calling either for receipt by him of a valuable performance or of the right to payments, assignment of a single contract to the lender, either on a percentage of receipts basis or as a whole, is entirely practical. In such case, the credit of the obligor is one aspect of value of the contract right; where the obligor's credit is superior to that of the borrower, the latter can avail himself of a lower rate of interest than that which he would ordinarily be required to pay. This is particularly true if the obligor assents to the assignment. But even under a nonnotification arrangement, assignment of a single contract right has advantages for both borrower and lender.

17. See note 71 infra and accompanying text. For a discussion of the problems arising from the assignor's intervening bankruptcy resulting in discharge of the obligor's duty to render the promised performance, see note 156 infra and accompanying text.

18. Malone v. Bolstein, 151 F. Supp. 544 (N.D.N.Y. 1956), aff'd, 244 F.2d 954 (2d Cir. 1957) (attempt by trustee in bankruptcy to have payments made under a conditional assignment within four months of bankruptcy set aside as preferential denied); In $r e$ New York, N.H. \& H.R.R., 25 F. Supp. 874 (D. Conn. 1938) (conditional assignment upheld in reorganization); notes 140-44 infra and accompanying text. 
of rights. ${ }^{19}$ Later respected in equity, the practice of assignment became so commercially significant that law courts also acceded, although they initially required the assignee to sue in the name of his assignor. ${ }^{20}$ But since a partial assignee was unable to join in an action at law all parties with rights in the assigned res, partial assignments remained enforceable only in equity. ${ }^{21}$ Where this limitation on joinder continues in effect, ${ }^{22}$ the partial assignee's enforcement possibilities are still so restricted; the assignment of a partial fixed sum or a fixed percentage of contractual rights is denied the status of a legal assignment. ${ }^{23}$ In most jurisdictions, however, procedural rules are presently no obstacle to the creation of assignments enforceable at law. ${ }^{24}$ And the

19. See 4 CoRbIN $\$ 856$; Ferson, The Assignnent of Contracts, 2 U.C.L.A.L. Rev. 303, 304 (1955). For interpretations of the unenforceability of assignments at common law, see Hanna, Contemporary Utility of General Assignments, 35 VA. L. Rev. 539 (1949); Winfield, Assignment of Choses in Action in Relation to Maintenance and Champerty, 35 L.Q. REv. 143 (1919).

20. REPORT 369: "There. has been some difference of opinion among legal writers as to whether the assignment of a chose in action today amounts to a legal transfer (i.e., of title), or is still merely the result of enforcement, on equitable principles, of the assignor's duty to his assignee, aided by the procedural union of law and equity and the statutes authorizing suit in his own name by the real party in interest." The Commission refers to a present transfer of an existing right as a legal assignment and uses the term equitable assignment to describe the transfer giving the more limited right of one who has been promised an assignment of a future right. In this Comment, the term legal assignment will refer to a transfer which is valid against all third parties; equitable assignment will describe those transfers which create more limited rights in the assignee. See, e.g., 4 PoMreroy, Equity Jurisprudence $\$ \$ 1270-72$ (5th ed. 1941) (hereinafter cited as POMERoy).

21. See 4 Corbin $\S 889$; Mandeville v. Welch, 18 U.S. (5 Wheat.) 277 (1820) (partial assignee unable to sue in the name of his assignor).

22. For states requiring or permitting joinder of parties, see ClaRK, Code Pleading 358 n.48, 365 n.72, 369 n.94, 371 n.99 (2d ed. 1947).

23. Thus, the rights of a partial assignee would be subordinated to the claim of a subsequent assignee of the entire res. The rule that a prior assignee prevails over a subsequent assignee would not control. See Judson v. Corcoran, 58 U.S. (17 How.) 611 (1854), in which the prior partial assignee of a chose in action was subordinated to a subsequent assignee of the entire claim who had filed notice of his interest with the Department of State. But see RESTATEMENT, Contracts $\$ 156$ (1932), which states that the right of the partial assignee is not cut off by a subsequent total assignment; REPORT 369. According to Williston, the Restatement's position is explicable if all assignments are viewed as equitable in nature. Williston, Is the Right of an Assignee of a Chose in Action Legal or Equitable?, $30 \mathrm{HARv}$. L. Rev. 97 (1916). See also Glenn, The Assignment of Choses in Action; Rights of Bona Fide Purchaser, 20 VA. L. Rev. 621, 626-27, 630 (1934).

24. See note 22 supra. In Madison Pictures, Inc. v. Chesapeake Industries, Inc., 147 N.Y.S.2d 50 (Sup. Ct. 1955), the court allowed an assignor to retain a cause of action for past breaches of contract yet assign executory rights under the contract. In Seamon v. Federated Films, Inc., 142 N.Y.S.2d 324 (N.Y. City Ct. 1955), the assignor had validly assigned both fixed sums and percentages of an anticipated fund. And in Sillman v. Twentieth Century-Fox Film Corp., 2 App. Div. 2d 662, 152 N.Y.S.2d 6 (1st Dep't 1956), rev'd, 3 N.Y.2d 395, 144 N.E.2d 387 (1957), multiple plaintiffs claimed as assignees under partial assignments. Assignees who were without the jurisdiction were held not 
distinction between legal and equitable assignments which persists has an implication other than that originally comprehended by the terms.

A legal assignment is created by the conveyance of property rights from assignor to assignee. Most exemplative of intangibles capable of legal transfer is a present right to existing property. Equally available for effective conveyance is a present interest in property not yet existing as typified by an executory contract. ${ }^{25}$ The potential assignor has a present interest in payments due upon his future performance. Such a right, however, must be clearly distinguished from an expectancy-property to which a party has no enforceable claim but of which he anticipates possession at some future date. ${ }^{26}$ Only in a limited

indispensable parties, and title to the res was declared without their appearance in the action. But cf. Restatentent, Contracts $\$ 156$ (1932), which states that the obligor is entitled to have all persons enjoying a collective right to the entire performance joined in the proceeding.

25. E.g., Malone v. Bolstein, 151 F. Supp. 544 (N.D.N.Y. 1956), aff'd, 244 F.2d 954 (2d Cir. 1957) ; Rockmore v. Lehman, 129 F.2d 892 (2d Cir. 1942) ; Scarborough v. Berkshire Fine Spinning Associates, 128 F. Supp. 948 (S.D.N.Y. 1955).

26. Rockmore v. Lehman, 128 F.2d 564, rev'd on rehearing, 129 F.2d 892 (2d Cir. 1942 ), distinguished between the two types of interests in classifying as legal an assignment of future installments to become due under an existing contract. In the earlier decision, the court thought the assignment at best only created an equitable lien which would disappear against an execution creditor or trustee in bankruptcy who under $\S 70(\mathrm{c})$ of the act occupies the position of a judgment creditor armed with an execution. $128 \mathrm{~F} .2 \mathrm{~d}$ at 567. The dissent, adopted on rehearing, stated: "I do not believe the decisions require so ancient a theory as that an assignment of definite contract rights, future only in the sense that they are conditioned upon the performance which the promisee has promised, is only a promise to pay out of future funds and not a present transfer." 128 F.2d at 567.

Assignments of future rights not arising out of an existing relationship or contract can only create an equitable assignment. Holroyd v. Marshall, 10 H.L. 191, 211 (1862); Tailby v. Official Receiver, 13 App. Cas. 523 (1888); cf. Sullivan v. Rosson, 223 N.Y. 217, 119 N.E. 405 (1918) (assignee of future rents who has done nothing to perfect his rights will not prevail over an execution creditor); State Factors Corp. v. Sales Factors Corp., 257 App. Div. 101, 12 N.Y.S.2d 12 (1st Dep't 1939). In Massachusetts, prior to the adoption of the Uniform Commercial Code, such assignments were invalid. Commercial Casualty Ins. Co. v. Murphy, 282 Mass. 100, 184 N.E. 434 (1933); Taylor v. Barton Child Co., 228 Mass. 126, 117 N.E. 43 (1917) ; Low v. Pew, 108 Mass. 347 (1871). But of. Gardner v. Hoeg, 35 Mass. (18 Pick.) 168 (1836).

However, in a few states, case law gives full effect to assignments of nonexistent rights to property. Thus, in Northwestern Nat'l Bank v. A. M. Cameron Co., 210 F.2d 398 (Sth Cir. 1954), where future accounts were held not capable of legal assignment, the court intimated that future accounts would have been assignable if identified properly. 39 Mrnw. L. Rev. 892 (1955). And, in Michigan, by case law preceding statutory enactment, such assignment was capable of creating a legal right in the assignee. Union Trust Co. v. Bulkeley, 150 Fed. 510 (6th Cir. 1907).

Moreover, statutes in several jurisdictions apparently would treat such transfers for security as legal assignments. Comment, 67 Y ALE L.J. 402, 416 n.44 (1958); see note 98 infra.

Nevertheless, confusion may result because of varying designation of fully valid assignments as equitable or legal. E.g., in Hinkle Iron Co. v. Kohn, 229 N.Y. 179, 128 N.E. 113 (1920), an assignment of a designated payment to become due to the assignor under an existing contract was upheld as a valid "equitable assignment." 
number of jurisdictions may an expectancy support a legal assignment. ${ }^{27}$ While the basis for distinguishing between present and anticipated rights is uncertain, the corollary requirement that an assigned right be identifiable has in part furnished a rationalization. ${ }^{28}$ The courts at common law, unsympa-

27. For cases denying validity to such an assignment, see, e.g., Clanton Bank v. Robinson, 195 Ala. 194, 70 So. 270 (1915) ; Ellis v. Saline County Coal Co., 199 Ill. App. 219 (1916) ; In re Nelson's Estate, 211 Iowa 168, 233 N.W. 115 (1930). But see Union Trust Co. v. Bulkeley, 150 Fed. 510 (6th Cir. 1907); H. D. Roosen Co. v. Pacific Radio Pub. Co., 123 Cal. App. 525, 11 P.2d 873 (1932); Cohen \& Gerber, supra note 1, at 557 n.11 (collecting cases). However, even where future property is not predicated upon present rights, equity has enforced assignees' interests on the theory of automatic accrual. Sexton v. Kessler \& Co., 225 U.S. 90 (1912) ; Mitchell v. Winslow, 17 Fed. Cas. 527, No. 9673 (C.C. Me. 1843) ; Baskin v. Aetna Life Ins. Co., 190 Ark. 448, 79 S.W.2d 724 (1935). Under this theory, the property, when acquired, automatically accrues to the assignee's equitable lien which is then perfected.

As to the technical distinction between an equitable assignment and an equitable lien, see In re Interborough Consol. Corp., 288 Fed. 334, 348 (2d Cir.), cert. denied, 262 U.S. 752 (1923) ; REPORT 409.

Temporizing between a rule which denied validity to assignments of expectancies and one which would validate all assignments of future rights, some jurisdictions adopted the doctrine of potential possession. Thus, although no contract exists under which rights can be assigned, an assignment will be given legal protection if a relationship out of which such rights are reasonably anticipated to arise can be found. Stokely Bros. \& Co. v. Conklin, 131 N.J. Eq. 552, 26 A.2d 147 (Ch. 1942) ; Claycraft Co. v. John Bowen Co., 287 Mass. 255, 191 N.E. 403 (1934) (no contract but an existing relationship). This protection may be granted on the theory that the original assignment, while equitable, becomes perfected automatically as the rights come into existence. Holroyd v. Marshall, 10 H.L. 191, 211 (1862) (assignee of after-acquired machinery prevailed over judgment lienor who attached subsequent to the acquisition of the machinery). It also may be rationalized on a simpler theory-that the original assignment was legally valid, as it would have been if the rights assigned had arisen from an existing contract. Jamestown Veneer \& Plywood Corp. v. Andrews, 93 F.2d 989 (3d Cir. 1938) (assigned future accounts valid security against trustee in bankruptcy who collected them) ; Seamon v. Federated Films, Inc., 142 N.Y.S.2d 324 (N.Y. City Ct. 1955) (assignment made one day before contract executed upheld as a legal assignment against judgment creditors); H. D. Roosen Co. v. Pacific Radio Pub. Co., supra.

The rule generally applicable grants equitable enforcement to an assignment of an expectancy but demands a further act, either reduction to possession or further assignment of the right when it comes into existence, for the assignment to be accorded legal validity. New York Sec. Co. v. Saratoga Gas \& Light Co., 159 N.Y. 137, 53 N.E. 758 (1899) (corporate mortgage encompassing future earnings and profits ineffective against general creditors until actual entry and possession); Smith v. D. A. Schulte, Inc., 91 F.2d 732 (2d Cir. 1937) (mortgage of future rents to be derived from mortgaged land invalid against trustee in reorganization proceeding); Sullivan v. Rosson, 223 N.Y. 217, 119 N.E. 405 (1918) (junior mortgagee could prevail over prior mortgagees of rents and profits of mortgaged premises by taking possession); In re McCrory Stores Corp., 73 F.2d 270 (2d Cir. 1934) (lessor's lien on money which could become due lessee if property sublet held invalid against trustee in bankruptcy).

28. In Fischer v. Liberty Nat'1 Bank, 53 F.2d 856, 857 (S.D.N.Y. 1931), an assignment of a receiver's compensation was held void: "Until ascertained and allowed, the compensation payable to a receiver is not at his disposal and cannot be assigned." But cf. Williams v. Ingersoll, 89 N.Y. 508, 518 (1882): "courts of equity will support assignment, 
thetic to conveyance of intangibles, determined that interests which an assignor did not possess at assignment were not susceptible to the requisite specific identification. Nonetheless, the present-future dichotomy is continued even where the requirement of identification could be fulfilled, largely in an attempt to restrict a lender's ability to secure well into the future all available resources of the borrower. ${ }^{29}$

When a party to a contract assigns his existing right and remedy, the performances due him in the future are impressed with the assignment as they mature and are treated as if transferred at the date of assignment. ${ }^{30}$ That the value of the interest is contingent at the time of assignment, because subject to defeat by default, repudiation or other breach of the underlying contract, does not preclude a valid transfer. ${ }^{31}$ Absent invalidation by the subsequent conduct of assignee or assignor, the assignment encompasses performances rendered and is superior to any later interest created in the assigned property..$^{32}$ The legal assignment of existing property thus offers the lender a valuable security.

In contrast, an equitable assignment is an unreliable security device. The equitable classification attends ineffective attempts at creation of legal assignments generally ${ }^{33}$ as well as the more specific conveyance of a future, non-

not only of choses in action, and of contingent interests and expectancies, but also of things that have no present, actual or potential existence, but rest in mere possibility; not, indeed, as a present, positive transfer, operative in presenti, for that can only be of a thing in esse, but as a present contract to take effect and attach as soon as the thing comes in esse"; MrcCluer v. Heim-Overly Realty Co., 71 F.2d 100 (Sth Cir. 1934) (assignment not insufficient for vagueness, ambiguity and failure to identify the property assigned, because word "estimates" under a building contract was part of the identification of the assigned proceeds) ; Northwestern Nat'1 Bank v. A. M. Cameron Co., 212 F.2d 484 (8th Cir. 1954); In re Cincinnati Iron Store Co., 167 Fed. 486 (6th Cir. 1909); In re Joseph, 43 F.2d 252 (M.D.N.C. 1930) (necessity for compliance with formal requisites to make a valid transfer) ; Zartman v. First Nat'l Bank, 189 N.Y. 267, 82 N.E. 127 (1907).

29. In re Cotton Manufacturers' Sales Co., 209 Fed. 629, 639 (E.D. Pa. 1913) : "It is doubtful even where there is no insolvency at the time of the execution of the agreement ... whether 'under the law of the state of Pennsylvania an assignment of all the assignor's future book accounts, without limit as to time, as security for present and future indebtedness to the assignee, without limit as to amount, may be enforced in equity against the creditors of the assignor, or against the assignor's trustee in bankruptcy.' The effect of such an agrcement would be to enable the assignee to be the secret owner of all the intangible assets of the assignor with the right to appropriate them at his pleasure without regard to the real status with reference to their ownership." See 2 MINN. L. REv. 38, 42-43 (1917). Contra, Field v. Mayor, 6 N.Y. 179, 186-87 (1852).

30. Scarborough v. Berkshire Fine Spinning Associates, 128 F. Supp. 948 (S.D. N.Y. 1955); In re Ace Fruit \& Produce Co., 49 F. Supp. 986 (S.D.N.Y. 1943).

31. 4 CoRbin $\$ 874$ n.8; American Employers Ins. Co. v. School Dist., 99 N.F. 188, 107 A.2d 684 (1954).

32. See note 37 infra and accompanying text.

33. Where clear words of present conveyance are used, but a present conveyance cannot be effected due to nonexistence of the rights in question, or where a promise to transfer a designated res can be found, an equitable interest in the subject matter arises in favor of the putative assignee. Porter v. Searle, 228 F.2d 748 (10th Cir. 1955) (promise to give 
existent right. ${ }^{34}$ The latter are treated as promises to assign which, though consistently enforced in equity against the assignor, ${ }^{35}$ are frequently subordinated to later arising third-party interests. ${ }^{36} \mathrm{~A}$ legal assignment for value and without notice is universally deemed to prevail over a prior equitable transfer. ${ }^{37}$ Judgment creditors in many jurisdictions will also take precedence

a chattel mortgage, followed by a refusal to do so, creates an equitable lien in favor of the prospective mortgagee). But see Fischer v. Liberty Nat'l Bank, 53 F.2d 856 (S.D.N.Y. 1931). However, a promise to make an assignment is distinguished from a promise to pay out of a specified fund which creates no interest in the fund designated. In re Kienle's Estate, 202 Misc. 396, 109 N.Y.S.2d 496 (Surr. Ct. 1951), aff'd without opinion, 280 App. Div. 975, 117 N.Y.S.2d 467 (1st Dep't 1952) (promise to pay out of a specific fund not an equitable assignment thereof since the terms of the writing showed no intent to vest in the claimant a present interest or to effect an appropriation of the property for such purpose). Accord, Christmas v. Russell, 81 U.S. (14 Wall.) 69, 84 (1871); Williams v. Ingersoll, 89 N.Y. 508 (1882). But see Barnes v. Alexander, 232 U.S. 117 (1914), in which a promise to pay from an expected fund was held to create a valid equitable assignment which attached to the res as it came into existence. See also In re Interborough Consol. Corp., 288 Fed. 334, 351 (2d Cir.), cert. denied, 262 U.S. 752 (1923), discussing the sufficiency of appropriation necessary to distinguish a mere promise to pay out of a designated fund from an equitable assignment of that fund: "[A] mere giving of a check on an ordinary desposit account in a bank in the usual course of business in payment of past indebtedness does not amount to an equitable assignment . . . " UNIFORM Negotiabie Instruments Law $\S \S 127,189.4$ Pomeroy $\S 1283$ a states: "The English courts hold that not only a present appropriation by order on a particular fund operates as an equitable assignment, but also a promise or executory agreement to apply a fund in discharge of an obligation has the same effect in equity. The American courts do not generally accept this doctrine."

For a comparison of the scope of protection afforded legal and equitable assignments, see notes 37-46 infra and accompanying text.

34. While not relevant to the discussion in text, the equitable label also describes the transfer of an equitable res. 2 ScoTT, TRUSTs $\S 132$ (1956).

35. The assignor retains legal title to the chose in action but in equity is a trustee for his assignee. 4 CORBIN $\$ 877$. The absolute promise to assign is specifically enforceable. Id. § 904: "Usually it has been held that the assignor, at the time of the assignment, impliedly promises that he will do nothing to prevent or impede collection by the assignee. In case of breach of this implied promise, the assignee can maintain action for an appropriate remedy." The enforcement of the promise to assign, in equity, is subject to the assignor's defenses against the assignee. See, e.g., Tripp v. Brownell, 66 Mass. (12 Cush.) 376, 380 (1853). See also Restatement, Contracts $\$ 167$ (1932); 4 Corbin $\$ \$ 892-900$.

36. An equitable assignee will, of course, prevail over a subsequent equitable assignee. The first assignment, by transferring the assignor's equity of ownership, is rationalized as leaving him nothing to convey by a later transfer. 2 \& 4 PoMreroy $\$ \$ 721,1291$. Glenn, The Assigmnent of Choses in Action; Rights of Bona Fide Purchaser, 20 VA. L. REv. 621, 625, 647-48 (1934); Comment, 67 Yale L.J. 402, 407 n.25 (1958).

37. The American rule, stated in Salem Trust Co. v. Manufacturers' Finance Co., 264 U.S. 182 (1924), is that, as between successive assignees of the same rights whose claims are otherwise equal, the earlier in time is preferred. But where the later assignee obtains a legal assignment, he will prevail over a prior equitable assignee. Thus, a subsequent assignee who actually collects assigned proceeds has been allowed to retain them against the claim of a prior equitable assignee. Judson v. Corcoran, 58 U.S. 611 (1854); In re Rosen, 157 F.2d 997 (3d Cir. 1946) ; Cody Finance Co. v. Leggett, 116 F. Supp. 700 (D. Wyo. 1953); Rabinowitz v. People's Nat'l Bank, 235 Mass. 102, 126 N.E. 289 (1920). 
over an equitable assignee, ${ }^{38}$ as will an intervening contract creditor attaching the res in the possession of the assignor or obligor. ${ }^{39}$ Further, in the few jurisdictions granting priority to the first assignee to notify the obligor of his assignment, ${ }^{40}$ the rights of an equitable assignee could conceivably be sub-

The same result may obtain, in regard to accounts receivable, under filing acts which allow an assignee for value and in good faith to retain proceeds which he has collected. Vt. Acts 1953, No. 164; Kan. Gen. Stat. Ans. \$\$ 58-801 to -807 (Supp. 1957).

The English rule, according priority to the first assignee to notify the obligor irrespective of time of assignment, is stated in Dearle v. Hall, 3 Russ. 1 (Ch. 1823), and is followed in a minority of American jurisdictions. See Corn Exchange Nat'l Bank \& Trust Co. v. Klauder, 318 U.S. 434 (1913), applying it to accounts receivable assignments.

While of diminishing importance in the accounts receivable field since the passage of validation and recordation statutes, Koessler, New Legislation Affecting Non-Notification Financing of Accounts Receivable, 44 MrcH. L. REv. 563 (1946), and since the amendment of the Bankruptcy Act in 1950 changing the bona fide purchaser test of perfection to a judicial lien creditor test, the alternative of notification as a means of legal perfection against a subsequent assignee is preserved by some statutes, see note 40 infra, and may exist in the common law of states not adopting accounts receivable recordation or validation statutes.

38. Matter of Gruner's Estate, 4 Misc. 2d 471, 74 N.Y.S.2d 38 (Surr. Ct. 1947) (judgment creditor whose lien attached subsequent to equitable assignment of future proceeds of sale of a stock exchange seat, but prior to sale, prevails over equitable assignee).

"The undoubted general rule . . . is that as between a judgment creditor's lien and the equitable lien of an assignee of property subsequently to be acquired, the latter, while his rights will be enforced in equity as against his assignor, has no right at all against the former." In the Matter of City of New York v. Bedford Bar \& Grill, 2 N.Y.2d 429, 141 N.E.2d 575 (1957). See, e.g., Cohen \& Gerber, The After-Acquired Property Clause, 87 U. PA. L. REv. 635 (1939).

39. Menick v. Carson, 96 F. Supp. 817 (S.D. Cal. 1951) (simple contract creditor who extended credit after assignment but before filing, where recordation was applicable means of perfection, allowed to recover proceeds already collected by assignee); Taylor v. Barton Child Co., 228 Mass. 126, 117 N.E. 43 (1917); Low v. Pew, 108 Mass. 347 (1871) ; New York Security \& Trust Co. v. Saratoga Gas \& Elec. Light Co., 159 N.Y. 137, 53 N.E. 758 (1899) (mortgage covering all corporate property including choses in action and future profits ineffective against creditor who had receiver appointed before the mortgagee foreclosed); Smith v. D. A. Schulte, Inc., 91 F.2d 732 (2d Cir. 1937) (lessor mortgaged land together with right to receive all rents due or to become due; held: until mortgagee gets a foreclosure receiver or the equivalent, all rents belong to the mortgagor and are subject to attachment by creditors and the trustee in bankruptcy).

But see: "An attaching creditor stands on no better footing than does his debtor and is subject to all existing liens created by his debtor. Therefore, if a debtor has no equitable interest a creditor acquires nothing by attachment." Seamon v. Federated Films, Inc., 142 N.Y.S.2d 324, 329 (N.Y. City Ct. 1955) ; 1 \& 2 Poumeroy $\S \$ 168,721$.

40. See note 4 supra. The rule prevails today in Mississippi, Canton Exchange Bank v. Yazoo County, 144 Miss. 579, 602, 109 So. 1, 4 (1926), and Tennessee, Moran v. Adkerson, 168 Tenn. 372, 79 S.W.2d 44 (1935). For a complete list of states which formerly adhered to this rule, see Koessler, Assignnent of Acconnts Receivable, 33 CALIF. L. Rev. 40,70 n.105 (1945). Even under recordation statutes, notification of the obligor is sometimes preserved as an alternative means of perfection. GA. CODE ANN. $\S \S 85-1806$ to -1813 (1955); Mo. AnN. Stat. $\S \S 410.010-.060$ (Supp. 1957); N.C. GEN. STAt. $\$ \S 44-47$ to -85 (Supp. 1955). 
ordinated to the interests of a subsequent equitable transferee. Under the Bankruptcy Act, moreover, the equitable conveyance is equally vulnerable to the creditor interests represented by the trustee. As provided by section 60 (a) (2), transfers which under applicable state law would have been subject to the attack of judicial lien creditors will be treated as preferences voidable by the trustee. ${ }^{41}$ And section $60(a)(6)$, denying recognition to equitable liens on property capable of legal assignment, ${ }^{42}$ implements a policy of eliminating the "doctrine of relation back," formerly applied to the equitable assignment in bankruptcy proceedings. This doctrine clothed an equitable assignment subsequently perfected into a legal interest with legal validity from the date of the original conveyance. ${ }^{43}$ Now, otherwise voidable assignments arising within the four-month voiding period prior to bankruptcy are no longer

41. 52 Stat. 869 (1938), as amended, 11 U.S.C. $\$ 96$ (1952). See 3 Collier, BankRURTCY \ 60.39 (14th ed., Moore 1956) (hereinafter cited as ColLIER).

42. Section 60 of the Bankruptcy Act of 1938 was revised specifically to permit the trustee in bankruptcy to avoid equitable assignments which would otherwise have been valid transfers in bankruptcy as valid under state law. Oglebay, supra note 2. After the decisions in Corn Exchange Nat'l Bank \& Trust Co. v. Klauder, 318 U.S. 434 (1943); In re Vardaman Shoe Co., 52 F. Supp. 562 (E.D. Mo. 1943), and In re Harvey Distributing Co., 88 F. Supp. 466 (E.D. Va. 1950), which subordinated the rights of prior assignees to those of subsequent assignees who first notified their respective obligors, the section was amended by substituting a judicial lien creditor test of perfection for the prior bona fide purchaser test. 64 STAT. 24 (1950), 11 U.S.C. \& 96 (1952). Thus, only transfers initially valid under state law against liens obtainable by legal or equitable proceedings, or so perfected before the four-month period preceding the filing of the petition in bankruptcy, were to be valid in bankruptcy. Moore \& Tone, Proposed Bankruptcy Amendmctst: Improvement or Retrogression?, 57 Y ALE L.J. 683 (1948). To insure that the 1938 version of the section would not be emasculated by this change of tests, $\S 60(a)(6)$ was added. The purpose of this section "is to make it certain that the amendment will not validate, in the hands of a secured creditor, equitable liens where available means of perfecting legal liens have not been employed." H.R. Rep. No. 1293, 81st Cong., 2d Sess. 7 (1949); Collrer, Bankruptcy ACT 95 (pamphlet ed. 1952). Thus, $\$ 60$ (a) (6) applies to a transfer which is equitable, but which is valid under $\$ 60(a)(2)$ since it would prevail over the lien of a judgment creditor under applicable state law, and declares that, where means of obtaining a legal interest are available but have not been employed, the transfer will be vulnerable in bankruptcy.

43. Sexton v. Kessler \& Co., 225 U.S. 90 (1912), enunciated a theory of relation back for the perfection of an equitable pledge to the date at which the original assignment was made. Thus, an assignment of a future right, which actually arose in the bankrupt's hands or which was perfected by a required further act such as reassignment, delivery of schedule of existing rights or recording within four months of bankruptcy, would be treated as "relating back" to the date of the original instrument. The subsequent lien was valid in bankruptcy if the equitable assignment had been made outside of the four-month period. For a full discussion of the doctrine of relation back and equitable liens, see REPORT 84104. Relation back still applies in a sense to performances or rights arising within four months of bankruptcy under a legal assignment. Scarborough v. Berkshire Fine Spinning Associates, 128 F. Supp. 948, 952 (S.D.N.Y. 1955): "When an assignment has been perfected, it precludes from consideration as preferences payments or collections made during the four-months period immediately preceding the bankruptcy." Accord, In re Ace Fruit \& Produce Co., 49 F. Supp. 986 (S.D.N.Y. 1943). 
deemed enforceable because integral to an equitable lien created prior to that period. ${ }^{44}$

Since the pragmatic consequence of the label legal or equitable is so highly significant, a logical foundation for distinguishing between rights capable and incapable of legal transfer appears necessary. The present distinction between existent and nonexistent rights does not furnish such a criterion. Troubled by the future or indefinite nature of an existing contract right to future performance dependent upon occurrence of a specified condition other than exchange of consideration, ${ }^{45}$ courts have often assimilated assignments of such rights to transfers of nonexisting interests. ${ }^{46}$ Even were

44. Section 60 (a) (6), see note 42 supra, may be inefficacious. In Porter v. Searle, 228 F.2d 748 (10th Cir. 1955), a chattel mortgage on a shifting stock of goods was to be executed by the vendee of a retail store. The vendors, who never received the chattel mortgage, repossessed the store within four months of the vendee's bankruptcy, with knowledge of his insolvency. The court held that they had had no means of perfecting a legal lien, therefore, the acquisition of merchandise in enforcement of an equitable lien created by the contract of sale was not voidable under $\$ 60(a)(6)$. See also Danais v. M. De Matteo Constr. Co., 102 F. Supp. 874 (D.N.H. 1952), in which the surety under a construction contract, who completed performance, was accorded an equitable lien by subrogation which the court held valid under $\S 60$ (a) (6) since means of perfecting a legal lien were not available. The court felt that claimed assignments obtained at the same time would have been preferential. For criticism of Porter v. Searle, supra, see Notes, 69 Harv. L. Rev. 1492 (1956), 17 U. Pitt. L. Rev. 712 (1956), 5 UTAH L. Rev. 272 (1957). See, generally, 3 CoLliER If 60.50. As to the effect of $\$ 60(a)$ on secured transactions under the Uniform Commercial Code, see Countryman, The Secured Transactions Article of the Commercial Code and Section 60 of the Bankruptcy Act, 16 Law \& Contexrp. Prop. 76 (1951).

45. In re New York, N.H. \& H.R.R., 25 F. Supp. 874 (D. Conn. 1938) (right assigned conditional upon proceeds of sublessor's rents reaching a certain sum); American Indemnity Co. v. Allied Freightways, Inc., 325 Mass. 568, 91 N.E.2d 823 (1950) (right conditional on approval of transfer of operating authority by ICC) ; RESTATEMENT, CoNTRACTS $\$ 155$ (1932) ; 4 CoRBIN $\$ 875$; see note 141 infra and accompanying text.

46. In In the Miatter of City of New York v. Bedford Bar and Grill, 2 N.Y.2d 429, 141 N.E.2d 575 (1957), an assignment of the refund due on a liquor license deposit was denied legal validity. Arguing that the deposit could not be legally assigned until the date at which it was actually available for payment to the borrower, the New York Court of Appeals subordinated the assignee's interest to that of a tax lien filed a month after the assignee had recorded his notice of assignment.

The majority drew an analogy to mortgages of after-acquired property and principally relied on Zartman v. First Nat'l Bank, 189 N.Y. 267, 82 N.E. 127 (1907) (assignment of chattels to be manufactured in future) ; Titusville Iron Co. v. City of New York, 207 N.Y. 203, 100 N.E. 806 (1912) (assignment to landowner of construction materials if left at site of construction should contractor default). In these cases, judgment liens attaching after the property came into existence prevailed over prior assignments. The dissent stated that rules governing mortgage or pledge of future crops or after-acquired chattels were inapplicable to the assignment of a fund which arose out of an existing relationship and had a potential legal existence. In the Matter of City of New York v. Bedford Bar \& Grill, supra at 434,141 N.E.2d at 578.

The majority decision, per Desmond, $J$., distinguished In the Matter of Capitol Distributors Corp. v. 2131 Eighth Avenue, 1 N.Y.2d 842, 135 N.E.2d 726 (1956), in which an assignment of a refund arising out of disapproval of a liquor license was upheld as against 
the present-future dichotomy not enmeshed in judicial confusion, a new index of enforceability should be sought. When the distinction was originally formulated, courts may have assumed that future rights were too vague and speculative for identification sufficient to serve as a basis for transfer. ${ }^{47}$ But in many business contexts, future rights are no less susceptible to description or less definite in value than future performances arising under existing contracts. In certain institutional areas-accounts receivable, for examplefuture or expectant rights are often statistically estimable in terms of value and nature and may serve as the basis of informed business decisions to lend. ${ }^{48}$ Moreover, the existence of many unique contracts may be equally certain well in advance of their final formulation. ${ }^{49}$ Again, once formulated, a contract

a subsequent filing judgment creditor, as an assignment of a present interest rather than a fund to come into existence in the future. Froessel, J., dissenting, cited this case in support of his opinion. For discussion of the Bedford Bar $\mathcal{E}$ Grill case, see Notes, 43 CoRNezL L.Q. 289 (1958), 106 U. PA. L. REv. 608 (1958).

The New York liquor license cases display the confusion engendered by the futurepresent dichotomy. See In the Matter of Creditors of Vincent Guarino, 285 App. Div. 1161, 140 N.Y.S.2d 370 (2d Dep't 1955) ; Frank v. Lutton, 267 App. Div. 703, 48 N.Y.S.2d 137 (3d Dep't 1944) ; Palmer v. Tremaine, 259 App. Div. 951, 20 N.Y.S.2d 145 (3d Dep't 1940) ; Atlas Advertising Agency, Inc. v. Casa Cubana, Inc., 259 App. Div. 951,19 N.Y.S.2d 900 (3d Dep’ $₫$ 1940) ; Alchar Realty Corp. v. Meredith Restaurant, Inc., 256 App. Div. 853, 8 N.Y. S.2d 733 (3d Dep't 1939) ; Mariano v. Cathy House Chinese Restaurant, 199 Misc. 410, 106 N.Y.S.2d 325 (Sup. Ct. 1951) ; O'Neill, Inc. v. Ward, 4 Misc. 2d 470, 32 N.Y.S.2d 559 (Sup. Ct. 1941); Schaefer Brewing Co. v. Amsterdam Tavern, Inc., 171 Misc. 352, 12 N.Y.S.2d 701 (Sup. Ct. 1939) (assignments held invalid against intervening judgment creditor's lien) ; cf. Strand v. Piser, 291 N.Y. 236, 52 N.E.2d 111 (1943). Compare Hillsdale Distillery Co. v. Briant, 129 Minn. 223, 152 N.W. 265 (1915) (assignment valid).

In other fields, the New York courts have demonstrated greater willingness to uphold assignments. See Seamon v. Federated Films, Inc., 142 N.Y.S.2d 324, 329 (N.Y. City Ct. 1955) (assignment of proceeds to be realized from sale and distribution of a motion picture upheld against judgment creditors whose liens attached subsequent to assignment but prior to the sums coming due) : "The judgment creditors argue that the assignments were not effective when made because they transferred funds which were not in esse. This type of case does not turn on whether or not the subject matter of an assignment is in esse, but rather on the distinction between an assignment of rights under a presently existing contract and of rights to be created by promises in the future . ...

"In the case at bar, there was an agreement in existence at the time the assignments were made and funds could reasonably be anticipated. There was an outright transfer of a portion of these funds by the assignor to the assignee." See also Kniffin v. State, 283 N.Y. 317, 323, 28 N.E.2d 853, 855 (1940) (assignment of moneys due and to become due under a contract with the state, filed with the state, valid against the obligor, later liens, assignments and claims of general creditors).

47. See note 28 supra.

48. Thus, receipts from established theaters, restaurants, department stores and even pari-mutueis can be predicted within a margin of error as sufficient to permit the constant level of incoming moneys necessary for a loan based upon them. An analogous process of analysis is involved in the accounts receivable based loan since a continuous supply of accounts of equivalent value will be necessary if the revolving loan arrangement is to "revolve." The truly permanent nature of so-called current assets is pointed out in Kripke, supra note 12 , at $510-11,512-13$.

49. See, e.g., cases dealing with potential possession, cited note 27 sipra. 
may confer rights to earn valuable and collectively identifiable future benefits quite apart from the obligations of the immediate parties. The contract allowing exhibition of motion pictures, for instance, gives rise to a series of daily receipts which cannot be classified as the producer's performance. Similarly, a race track's license from the state creates anticipated pari-mutuel income which may be of sufficient worth to justify a loan.

A criterion of identifiability would accordingly appear a more realistic standard. Allowing assignment of nonexistent rights should not result to the detriment of general creditors. For all identifiable rights are equally amenable to procedures permitting third parties to ascertain the status of the assignor's credit. The only persuasive rationale for proscribing the assignment of future rights would be protection of borrowers against heedless dissipation of their future substance. But the class of borrowers for whom such safeguards are needed-the wage earner-is already protected by special statutes regulating assignment. ${ }^{50}$ And no reason appears for denying the commercial borrower the same freedom of contract in granting security as he is allowed in his other consensual dealings. Moreover, in practice, the end to be denied by the restriction on conveyance of future rights is presently achieved, either by statute in states which specifically permit such assignment ${ }^{51}$ or by means of the revolving loan agreement elsewhere. ${ }^{52}$ Giving validity to assignments of anticipated rights would, therefore, produce no substantive change in current commercial practices. Within the framework of outright enforceability, other problems would remain.

\section{The Negative Assignment Clause}

Frequently, one becoming party to a contract will seek to avoid any possible burdens of assignment by restricting transfer of any part of the contract by his promisee. ${ }^{53}$ The potential obligor may fear that absent such-re-

50. See, e.g., Fortas, supra note 5, at 554-58 (collecting statutes); of. Lehigh Valley R.R. v. Woodring, 116 Pa. 513, 519, 9 Atl. 58, 61 (1887) (assignment of all of a day laborer's future wages said to be against public policy): "A man may not sell himself into slavery."

51. Uniforar Conmercial Code \$ 9-204(3) (Ky., Mass., Pa.) ; Cal. Civ. Cone §§ 301729, H. S. Mann Corp. v. Moody, 144 Cal. App. 2d 310, 301 P.2d 28 (1956); Iowa CodE ANN. $\S \S 539.7-15$ (Supp. 1957) ; Mich. Stat. AnN. \$§ 19.841-.849, 19.851 (Supp. 1957) ; Tex. Rev. Civ. Stat. Ann. art. 260-1 (Supp. 1957) ; Kan. Gen. Stat. Ann. \$§ 58-801 to -807 (Supp. 1957) (semble).

52. Kripke, supra note 12, at 511: "[F] or the small businessman who is chronically undercapitalized, and to whom the conventional long-term sources of funds are not available, credit devices by which he is enabled to obtain the capital with which to carry his inventory or his accounts receivable, may, in fact, be credit devices for extending longterm credit even though the arrangements are nominally for the short term and are quickly terminable." For a description of the revolving loan agreement, see notes 137, 138 infra and accompanying text.

53. For a description and discussion of these provisions, see Grismore, Effect of a Restriction on Assignment in a Contract, 31 MICH. L. Rev. 299 (1933); 4 CoRBIN \$\$ 872, 
striction he could be forced to accept performance from a stranger-assignee. ${ }^{54}$ Or he may apprehend subjection to a multiplicity of third-party claims to the performance due his promisee. ${ }^{55}$ At one time, nonassignability provisions were regarded as void because they effected an undue restraint upon alienation of property. ${ }^{56}$ Despite the principle of freedom of assignability generally favored by modern courts, however, clearly worded negative assignment clauses have occasionally been upheld..$^{57}$

More often, courts have denied significance to negative assignment provisions by construing them to import a meaning other than that originally intended by the parties. The devitalizing construction most frequently em-

873; Notes, 1952 Wis. L. Rev. 740, 4 Fordhadr L. Rev. 178 (1952) ; Restatement, ConTRACTS \& 176 (1932).

54. See, e.g., 4 CoRBIN $\& 872$ n.85.

55. United States v. Hill, 171 F.2d 404, 406, 407 (5th Cir. 1948) ; Sillman v. Twentieth Century-Fox Film Corp., 3 N.Y.2d 395, 405, 144 N.E.2d 387, 393 (1957) (dissenting opinion) ; see Concrete Form Co. v. W. T. Grange Constr. Co., 320 Pa. 205, 209, 181 Atl. 589, 590 (1935); Joint School Dist. v. Marathon County Bank, 187 Wis. 416, 204 N.W. 471 (1925).

56. Note, 1952 WIs. L. REv. 740, 742: "The right to receive payment has been held analogous to a chattel so that any restriction on alienation was found invalid. Statutes declaring choses freely assignable have been construed mandatory and thus militating against any restrictive provision." See also State Street Furniture Co. v. Armour \& Co., 345 Ill. 160, 177 N.E. 702 (1931) (assignment of wages due or to become due valid, despite nonassignment clause, for alienation of a property right could not be restricted). This reasoning was held inapplicable by the New York Court of Appeals in Allhusen v. Caristo Constr. Corp., 303 N.Y. 446, 452, 103 N.E.2d 891, 893 (1952) (negative assignment provision valid), which cited as support 2 Williston, Contracts $\$ 422$ (rev. ed. 1936).

57. In Allhusen v. Caristo Constr. Corp., supra note 56, at 449, 103 N.E.2d at 891 , the contract provided: "The assignment by the second party [subcontractor] of this contract or any interest therein, or of any money due or to become due by reason of the terms hereof without the written consent of the first party [general contractor] shall be void." The subcontractor assigned the right to moneys without the consent of the general contractor; the assignee's attempt to collect was unsuccessful since the assignment was held void. See also Parkinson v. Caldwell, 126 Cal. App. 2d 548, 552-53, 272 P.2d 934, 937 (1954) ; Lewin \& Sons, Inc. v. Herman, 143 Conn. 146, 149, 120 A.2d 423, 425 (1956) : Annot., 37 A.L.R.2d 1251 (1954). In Green v. Camlin, 229 S.C. 129, 92 S.E.2d 125 (1956), an attempted assignment of an automobile agency franchise was held void, and the assignee recovered the consideration given for the assignment. But, even absent the prohibition against assignment, the assignor could not have delegated his agency to another, his contract being personal.

When the contractual provision is given effect to void the assignment, the assignee for security retains only his claim against the assignor and an equitable lien on the assigned property. Grismore, supra note 53, at $306 \mathrm{n} .19$ (collecting cases). However, the assignee's equitable right against his assignor may be of little value if the assignor is bankrupt. The equitable lien would be ineffective in bankruptcy, and the trustee would undertake collection from the obligor. See notes 41-44 supra and accompanying text. See also 4 Collier If $70.43,70.44$ (discussing the effect of such a clause in bankruptcy); New York Trust Co. v. Island Oil \& Transp. Corp., 34 F.2d 653 (2d Cir. 1929). But sec Miller v. Fredeking, 101 W. Va. 643, 133 S.E. 375 (1926); Note, 25 U. CHI. L. Rev. 199, 201 nn.12 \& 13 (1957). 
ployed finds such a clause to be a promise not to assign the contract. 58 So construed, the provision would render an assigning party liable in damages for breach rather than invalidate the assignment. While the obligor would be excused from rendering performance and the assignment would in effect be void if the breach were held material, rarely if ever could a court be expected to find the damages sufficiently great to warrant repudiation. ${ }^{59}$ Alternatively, courts have considered the negative assignment clause a stipulation that transfer by one party authorizes his promisee to call a forfeiture of the contract. ${ }^{60}$ Although not precluding the power to assign, such an interpretation does make any assignment of doubtful value unless prior assent of the obligor is obtained, since the nonassigning party may invalidate the underlying contract. But here again, courts, either by requiring strong objective acts of repudiation or

58. Fortunato v. Patten, 147 N.Y. 277, 41 N.E. 572 (1895) (negative-assignment clause in constryction contract with City of New York did not bar the power to assign; prior assignee prevailed over subsequent assignee who took with consent of the obligor). In Empire Discount Corp. v. William E. Bouley Co., 160 N.Y.S.2d 395, 397 (Sup. Ct. 1957), defendant, a general contractor, paid a fund allegedly assigned to plaintiff by its subcontractor to the latter who became insolvent. The assignee sued the obligor. The subcontract contained the following clause: "Neither party to this contract shall assign the contract without written consent of the other, nor shall the Subcontractor assign any moneys due or to become due to him hereunder without the previous written consent of the contractor." The court interpreted this clause as a mere personal covenant on the part of the subcontractor not to assign without written consent; it did not void the assignment.

See Grismore, supra note 53, at 300, 301-05; cf. Note, 1952 WIs. L. Rev. 740 n.7. But see Burck v. Taylor, 152 U.S. 634 (1894), a suit by the partial assignee against subsequent assignee for accounting. The Court regarded the first assignment as nugatory due to the nonassignment clause; the second assignee, having taken his assignment with consent of the obligor, prevailed.

59. See Note, 1952 WIs. L. REv. 740, 742: "The effect of calling the clause promissory is very close to finding it invalid, for it would be quite difficult to prove more than nominal damages for breach of such a provision." See also Grismore, supra note 53, at 605: "No case has been found in which a court has held that a contract may be forfeited for breach of a mere covenant or promise to refrain from making an assignment .... It is not surprising that no such cases have been found. If the contract were of such a character as to justify the court in saying that an assignment of it would constitute a material breach, so that performance of the promise might be said to be a constructive condition precedent, it would probably also be true that the assignment would be invalid under the rules of law which, even today, do not permit the assignment of so-called personal rights and duties." See also Empire Discount Corp. v. William E. Bouley Co., stpra note 58 (assignor's insolvency prevented any recovery for damages by the obligor on the breach of the covenant not to assign) ; Sacks v. Neptune Meter Co., 144 Misc. 70, 258 N.Y. Supp. 254 (Sup. Ct. 1932), aff'd, 238 App. Div. 82, 263 N.Y. Supp. 462 (1st Dep't 1933) ; Hull v. Hostettler, 224 Mich. 365, 369, 194 N.W. 996, 997 (1933). If damages did exist, however, the obligor should be able to set them off against the assignee. 4 Corbin $\$ 896$, at 596; 2 Williston, Contracts $\$ \$ 433,435$ (rev. ed. 1936); Uniform Conmarerial Cone \$ 9-31S(1).

60. Snyder v. Bernstein Bros., 201 Iowa 931, 208 N.W. 503 (1926) (lease) ; Merrill v. New England Mut. Life Ins. Co., 103 Mass. 245, 252 (1869) (insurance contract). 
through principles of waiver and estoppel, may be expected to alleviate the severity of the interpretation. ${ }^{61}$

Other courts have accomplished the same result by completely ignoring negative assignment provisions where an assignment is made for security. Arguing that an assignment for security will not require the obligor to accept performance from anyone other than his promisee, these courts have analogized the transfer to a mortgage rather than a true assignment. ${ }^{62}$ Unlike strained construction, this judicial technique is conceptually unsound. For it overlooks the fact that a primary purpose of the provision is to avoid a multiplicity of claims. ${ }^{63}$ More important, an assignee for security may assume his assignor's performance to safeguard his interests. ${ }^{64}$

Even when a negative assignment provision is construed in accordance with its plain purport, its effect is conjectural. Intended solely for the benefit of the obligor, the right to invoke the clause to void an assignment might logically be restricted to him. ${ }^{65}$ But by its terms rendering void $a b$ initio any assignment of contract rights, the nonassignability provision would appear open to invocation by appropriate third parties to subject the res to their interests. The assignee would continue in rights superior to those of the assignor, however; for, if invalidated, the legal assignment should create an equitable lien on the proceeds held by the latter. ${ }^{86}$ Of course, this lien would have all the

61. 4 CoRBin $\S 873$, at 496 .

62. Crouse v. Michell, 130 Mich. 347, 90 N.W. 32 (1902) (lease assigned as collateral security valid); Inter-Southern Life Ins. Co. v. Humphrey, 122 Miss. 579, \&4 So. 625 (1920) (assignment of commissions as collateral security valid). Compare DixonReo Co. v. Horton Motor Co., 49 N.D. 304, 191 N.W. 780 (1922) (promise by an automobile dealer to a distributor not to assign the agreement or rights thereunder held not to prohibit assignment of money due under agreement), with Green v. Camlin, 229 S.C. 129, 92 S.E.2d 125 (1956) (assignment of an entire automobile franchise held invalid). See also Trubowitch v. Riverbank Canning Co., 30 Cal. 2d 335, 182 P.2d 182 (1947); UNIFORM COMIMERCTAL CODE § 9-318(4).

63. See note $\mathbf{5 5}$ supra. Commentators and courts have supported negative assignment clauses as necessary to protect the obligor from undue hardship in rendering performance, Sillman v. Twentieth Century-Fox Film Corp., 3 N.Y.2d 395, 405, 144 N.E.2d 387,393 (1957) (dissenting opinion), to prevent confusion as to the party to whom performance should be rendered, Hobbs v. McLean, 117 U.S. 567, 576 (1886); United States v. Hill, 171 F.2d 405, 406 (5th Cir. 1948), and to minimize purchases of claims, United States v. Aetna Cas. \& Surety Co., 338 U.S. 366, 373 (1949).

64. See notes 71-75 infra and accompanying text.

65. "A provision forbidding one party to make an assignment of his right is solely for the advantage of the other party who is under the correlative duty. That other party can waive the benefit of the provision, either before or after the assignment has been made." 4 Corbin $\$ 873$. Portuguese-American Bank v. Welles, 242 U.S. 7, 12 (1916).

66. Staples v. City of Somerville, 176 Mass. 237, 57 N.E. 380 (1900); see Service Purchasing Co. v. Brennan, 226 Mo. App. 110, 42 S.W.2d 39 (1931); cf. Martin v. National Surety Co., 300 U.S. 588 (1937) (statutory prohibition of assignment was for the benefit of the state only; when it chose to pay a subsequent assignee, the latter was declared to hold in trust for a prior assignee). 
imperfections of an equitable transfer both within and without bankruptcy. ${ }^{67}$ In any event, while stating that a negative assignment clause voids an attempted assignment of contract rights, the decisions usually invest such clauses with a more limited significance than the label void generally imports. In Sillman v. Twentieth Century-Fox Film Corp., for example, although a negative assignment clause was held to have voided a subsequent assignment, that effect was deemed conducive to waiver by the obligor. ${ }^{68}$ Logically, an obligor is incapable of rejuvenating an originally invalid assignment. Nevertheless, the decision found an assignment of rights in a contract containing a negative assignment provision permissible absent affirmative denunciation by the obligor. ${ }^{69} \mathrm{~A}$

67. The constructive trust or equitable lien in favor of the assignee arises as soon as the assigned property is acquired by the assignor. 4 ScorT, TRUsTs $\$ 462.4$ (1956). But since the absolutely void construction discussed in text would allow third parties to invalidate the assignment, notice to the obligor should not constitute a defense in garnishment proceedings. 2 POMEROY $\S 694$. If, therefore, the obligor would be discharged by paying a garnishing or execution creditor, such a lien would not be good in bankruptcy under $\$$ 60 (a) (2). See note 42 supra. However, if the proceeds were in the hands of the assignor, the assignee could compel payment; against the assignor, he has a valid equitable lien or right to enforce a constructive trust. If the lien was otherwise valid under $\S 60$ of the Bankruptcy Act, because it arose outside of the four-month period, see note 42 supra, and was not within the compass of $\$ 60(a)(6)$, the assignee would still have difficulty reclaiming the proceeds from a trustee in bankruptcy, 4 COLLIER $\llbracket 70.25$, at 1137; Wuerpel v. Commercial Germania Trust \& Sav. Bank, 238 Fed. 269 (5th Cir. 1917) (equitable assignee not entitled to trace fund which assignor received and converted). See also note 109 infra.

68. 3 N.Y.2d 395, 144 N.E.2d 387 (1957), reversing 2 App. Div. 2d 662, 152 N.Y.S.2d 6 (1st Dep't 1956). The clause read: "[N] either party hereto shall assign this agreement, in whole or in part, or any rights or monies payable hereunder, without the prior written consent of the other party." The New York Court of Appeals found Allhusen v. Caristo Constr. Corp., 303 N.Y. 446, 103 N.E.2d 891 (1952), controlling and held that the clause voided the assignment unless waived.

69. The court cited Hackett v. Campbell, 159 N.Y. 537 (1899) (obligor waived requirement of consent in writing by receiving notice of assignment without protest). But the Hackett court had not expressly construed the clause to void the assignment. Rather, it apparently found the obligor possessed of an obviously waivable promise not to assign. See also Kehoe v. Kehoe-Berge Coal Co., 388 Pa. 79, 130 A.2d 165 (1957). Nevertheless, the Sillman court may have found an estoppel in the obligor's conduct, or it may have meant that the clause made the assignment merely voidable, in which case waiver could, in effect, validate it. Grismore, supra note 53, at 307 n.24.

However, the voidable construction gives the obligor an option to bide his time in deciding whether or not to void the assignment. If bankruptcy were imminent, the obligor's decision to affirm the assignment would be crucial, and, arguably, preferential.

Eut if the assignment is void $a b$ intitio, yet capable of revivification by the obligor's subsequent consent, such consent within four months of bankruptcy would constitute a preference of the assignee, attackable by the trustee in bankruptcy under either $\S 60$, to recover from the assignee, or under $\S 67$ (d) (3), to recover from the obligor. It has, however, been held that the assignment is void only between assignee and obligor. Tezel \& Cotter v. Roark, 301 S.W.2d 179 (Tex. Civ. App. 1957). But see Grismore, supra note 53 , at $306-08$.

In recordation states, where filing is intended to perfect an assignment, a nonassignability clause in the contract which would void the assignment without the obligor's 
nonassignability provision accordingly should not present too great an obstacle. For a court will probably either interpret the provision as a mere promise in conformity with the basic policy of freedom of assignment, or, if according it voiding effect, determine that it was capable of waiver and was in fact waived. ${ }^{70}$ Since a diligent obligor can invalidate the assignment, however, obtaining his approval of a conveyance is advisable.

\section{The Option To Perform}

To insure maintenance of his security interest, a lender may seek to reserve in his assignment an option to assume and delegate performance of the underlying contract. ${ }^{71}$ In contrast to the institutionalized financing of accounts receivable, the security interest in long-term contract rights may easily be undermined by conduct of the assignor. ${ }^{72}$ Accounts receivable, while in practice

consent presents the possibility that a prior recording assignee may lose to a subsequent unrecorded assignee who receives consent. Cf. Opitz v. Karel, 118 Wis. 527,95 N.W. 948 (1903) ; Burck v. Taylor, 152 U.S. 634 (1894) ; Martin v. National Surety Co., 300 U.S. 588 (1937).

70. The dissent accused the Sillman court of trying to evade the harsh result of Allhusen v. Caristo Constr. Corp., 303 N.Y. 446, 103 N.E.2d 891 (1952), by taking a liberal view of acts sufficient to constitute waiver. 3 N.Y.2d at 407, 409, 144 N.E.2d at 394, 395. If the majority in fact was so motivated, its attitude was predicted by Gilmore, The Comnercial Doctrine of Good Faith Purchase, 63 Y ALE L.J. 1057, 1118 (1954) (criticizing Allhusen).

71. Assignments of rights as collateral security normally do not contemplate assumption of performance by the assignee. Silman v. Twentieth Century-Fox Film Corp., 3 N.Y.2d 395, 144 N.E.2d 387 (1957) ; Tel-Hotel Corp. v. Lexnott Corp., 124 N.Y.S.2d 159,165 (Sup. Ct. 1953) (assignment of license did not operate as assignment or assumption of liabilities of the original contract); 2 WuLListon, ConTRActs $\$ 418$ (rev. ed. 1936). Contra, Restatensent, Contracts $\$ 164(2)$ (1932).

However, since the assignor's failure to perform or render adequate performance on the underlying contract would give rise to a claim for damages by the obligor, which he is entitled to set off against the sum earned, see note 72 infra, such conduct by the assignor would negate the value of the assignment as security. Thus, the lender should be able to insist on his right, as against the assignor, to assume or delegate performance to forestall repudiation of the contract. A contract which could support such an option would be one under which the assignor was not required to render personal services or supervision. See Green v. Camlin, 229 S.C. 129, 92 S.E.2d 125 (1956) (attempted assignment of automobile agency franchise void; assignor's personal services required). Such an option would not relieve the assignor of his underlying liability on the contract since contractual duties are not assignable. But tender of performance by the assignee would satisfy the condition precedent to his right to the assigned performance. Devlin v. Mayor, 63 N.Y. 8 (1875); 4 CORBIN $\$ 865$, at 447-48: "[W]here the duty to pay for coal is conditional on certain installment deliveries being made, the making of these deliveries is a condition precedent to the seller's right to payment by the buyer; but the making of these deliveries is in no sense a personal performance. A tender of delivery by an assignee of the seller's right would fulfill the condition precedent and the assignee could then enforce the right against the buyer." Accord, British Waggon Co. v. Lea \& Co., 5 Q.B.D. 149 (1880).

72. The assignee for value is subject to all defenses and counterclaims of the obligor against the assignor which arose before the obligor received notice of the assignment. Wagner v. Central Banking \& Sec. Co., 249 Fed. 145 (4th Cir. 1918). But see Arlington Trust Co. v. United States, 121 Ct. Cl. 33, 100 F. Supp. 817 (1951) (assignee of contractor's 
utilized in long-term financing, are adjustable to sudden changes in the borrower's financial condition since they may generally be collected within a thirty-to-sixty-to-ninety day period. ${ }^{73}$ The right to payment arising under a long-term contract, on the other hand, may be destroyed by the borrower's inability or unwillingness to complete his performance. Nevertheless, completion of the contract could be of significant advantage to the lender. The contract may be sufficiently profitable that return from completion will far exceed any necessary outlay. ${ }^{74} \mathrm{Or}$, although the contract is not highly profitable in itself, performance may have been rendered the value of which would be lost if the contract were not completed by the assignor or his delegate. Thus, damages from breach may balance the value already earned and due. Even absent damages, if the contract or any of its stages were not substantially

claim against the United States allowed to collect sum his assignor would have been entitled to had he not been guilty of fraud). Where the assignor fails to complete performance, the obligor may set off the cost of completion against the assignee's claim. St. Mary's Bank v. Cianchette, 99 F. Supp. 994 (D. Me. 1951).

However, sums earned under the terms of the contract prior to breach are available to the assignee. Kniffin v. State, 283 N.Y. 317, 28 N.E.2d 853 (1940). And bankruptcy does not terminate a valid assignment. Great American Indemnity $\mathrm{Co}$. v. Allied Freightways, Inc., 325 Mass. 568, 91 N.E.2d 823 (1950) ; In re Italian Cook Oil Corp., 190 F.2d 994 (3d Cir. 1951).

Where there is a total failure of consideration on the part of the assignor, no sums are due under the contract; the assignee can collect nothing. As to the effect of the assignor's repudiation of the contract after part performance on the obligor's duty of payment, see Anderson, Repudiation of Contract: The Post-Restatement Cases, 6 DE PAUL L. REv. 1 (1956). The assignor's insolvency has not been held operative as an anticipatory breach of contract. 4 Corbin $\$ 985$. But see Central Trust Co. v. Chicago Auditorium Ass'n, 240 U.S. 581, 591 (1916), where it was stated: "Commercial credits are, to a large extent, based upon the reasonable expectation that pending contracts of acknowledged validity will be performed in due course; and the same principle that entitles the promisee to continued willingness entitles him to continued ability on the part of the promisor. In short, it must be deemed an implied term of every contract that the promisor will not permit himself, through insolvency or acts of bankruptcy, to be disabled from making performance; and, in this view, bankruptcy proceedings are but the natural and legal consequence of something done or omitted to be done by the bankrupt in violation of his engagement." Section $70(\mathrm{~b})$ of the Bankruptcy Act empowers the trustee to assume a contract. 4 CoLLIER If 70.43, 70.44; see notes $153-55$ infra and accompanying text.

73. Kripke, Current Assets Financing as a Source of Long-Term Capital, 36 Mins. L. REv. 505, 512-13 (1952).

74. If the assignor's right to perform is delegable, the obligor is not entitled to refuse a complying performance from the assignor's substitute, as long as the assignor has not repudiated his liability on the underlying contract. See note 71 supra. Tender of good performance by the assignee would prevent an implied repudiation where the assignor has ceased to perform or anticipates so doing. If the lender has made a large advance on the security of an assigned contractual right to proceeds, prevention of breach of contract may be to his advantage, even if he must undertake some expense in redelegating performance.

Charter restrictions might prevent a bank, as lender, from taking advantage of an option to assume and delegate performance. Stevens, CoRporatrons $\$ \$ 48,55-56$ (2d ed. 1949); 6 Fletcher, Cyclopedia of Corporations $\$ \$ 2622,2623$ (rev. ed. 1950). Other commercial lenders would presumably be able to do so. 
completed; recovery could only be had on a theory of quantum meruit, and the assignee's security would therefore be destroyed. ${ }^{75}$

Unless an option specifying the conditions upon which the assignee may assume performance is expressly incorporated in the written assignment, a choice to perform will rarely be available to the lender. In a number of jurisdictions, the assignment of a contract for security, unlike an unqualified assignment, does not of itself import a right to perform on the underlying contract. ${ }^{76}$ When the right to perform exists, ${ }^{77}$ either by law or agreement, express provision detailing the conditions precedent to assignee performance may be necessary to extricate the assignee from undesirable burdens which might otherwise accrue. ${ }^{78}$

Although such an option will generally be sufficient to allow the assignee performance when desired, the right to perform remains capable of destruction by the assignor. True, the assignor may reserve the right to assign the contract, and obligor will be bound to accept a good performance if the assignor's personal services are not required. ${ }^{79}$ But if the contract is repudiated by the assignor prior to assignee assumption and performance, the obligor is legally justified in treating the contract as terminated.80 An assignor

75. Under the Massachusetts view, even quantum meruit would be unavailable if substantial performance had not been rendered. See, generally, 3 CoRbrn $\$ 710$.

Recovery in quantum mernit would not inure to the assignee's benefit since it does not stem from the contractual right assigned.

76. See Restatement, Contracts \$ 164 (1932); note 71 supra.

Actually, the question of construction of the assignment contract is involved. Where it states that the assignment is made for security, the assignee will not be held to have been an outright purchaser who is obligated as well as entitled to perform. But when the assignment purports to assign the "contract" in question, the court must interpret whether delegation of rights only, or rights and duties, was intended. See 4 CoRBin $\$ 881$ n. $\$ 7$.

77. A nonassignment clause which effectually barred an assignment for collateral security of money performance would be held to bar assignment of the right to assign or delegate performance. See note 71 supra.

78. The secured lender does not intend to be a surety for performance; he desires only the benefits of return performance from the obligor. Only a clear option on the part of the assignee to assume and delegate performance could be advantageous to him; an unclear statement would risk interpretation as a surety arrangement. 4 CoRBIN $\$ \S 906,924$.

79. See note 71 supra.

80. Mere expressions by a party of his doubt as to his ability to perform under a contract will not constitute anticipatory repudiation. Wonalancet Co. v. Banfield, 116 Conn. 582, 165 Atl. 785 (1933) (buyer whose corporate existence had terminated told seller it doubted whether seller would desire to continue deliveries); F. W. Kavenaugh Mfg. Co. v. Rosen, 132 Mich. 44, 92 N.W. 788 (1902) (party's conduct giving rise to suspicion of insolvency does not amount to anticipatory repudiation). Nevertheless, statements or conduct showing inability to perform may justify the obligor in treating the contract as repudiated. Roehm v. Horst, 178 U.S. 1, 8 (1899) (buyer's anticipatory repudiation of contract) : "It is not disputed that if one party to a contract has destroyed the subject matter, or disabled himself so as to make performance impossible, his conduct is equivalent to a breach of the contract although the time for performance has not arrived; and also that if a contract provides for a series of acts, and actual default is made in the performance of one of them, accompanied by refusal to perform the rest, the other party 
is unlikely to repudiate a contract expressly without first consulting the assignee as to his willingness to complete; completion will reduce the obligation to the assignee as well as forestall liability for breach. However, termination may be justified not only by express rejection but by constructive repudiation in the form of the assignor's deteriorated performance or obvious inability to fulfill the contract. ${ }^{81}$ And since all rights under the contract, and the assignment, lapse once the contract is in fact repudiated, the assignee can only protect his security and complete performance by effecting a novation with the obligor. ${ }^{82} \mathrm{~A}$ more equitable rule would require the obligor to accept performance by the assignee unless he has detrimentally relied upon the repudiation, the assignor remaining the party primarily liable for breach..$^{83}$ Absent such reform, an assignee must vigilantly police his assignor's activities to make the option to perform fully effective.

\section{Perfection}

After a contract of assignment has been made, various technical operations are necessary to perfect the assignment-give it the effect contemplated by the parties. Historically, legal conveyance was accomplished by a single evidentiary act, change in possession. ${ }^{84}$ Even after property had become amenable to legal alienation through written instrument, transfers for security unaccompanied by immediate change in possession remained suspect. ${ }^{85}$ Due to the lack of notoriety accompanying the transfer, such agreements were

need not perform but may treat the refusal as a breach of the entire contract and recover accordingly."

See also 4 CoRbIN $\$$ 974, 984; Pike v. Waltham, 168 Mass. 581, 47 N.E. 437 (1897) ; Restatenient, Contracts $\$ 165$ (1932).

81. The assignor's insolvency is not itself operative as breach of contract. 4 CoRBIN $\$ 985$. But prospective failure of consideration, evidenced by the assignor's insolvency, excuses the obligor from rendering performance. See Ferson, Breach of Contract: Elements, Degrees and Effect, 24 U. CIN. L. Rev. 1, 20-22 (1955). See also note 72 supra.

82. Novation is the formation of a new contract between the parties, usually eliminating one of the prior promisors from the contractual relationship and substituting another in his place. 4 ConbrN $\$ 870 ; 6$ id. $\$ 1297$.

83. Such a rule would in effect extend to the assignee the assignor's power to retract his repudiation until the obligor has materially changed his position in reliance. United States v. Seacoast Gas Co., 204 F.2d 709 (5th Cir.), cert. denied, 346 U.S. 866 (1953); Rayburn v. Comstock, 80 Mich. 448, 45 N.W. 378 (1890).

84. The earliest security based on personalty was the pledge, which is dependent on change of possession for validity. See Gilmore \& Axelrod, Chattel Security I, 57 YALE L.J. 517, 521 n.10, 529 n.28 (1948).

S5. See Ferson, The Assignment of Contracts, 2 U.C.L.A.L. Rev. 303 (1955).

Statute of Fraudulent Conveyances, 1571, 13 ElIz. c. 5, predecessor of the UNIFoRM Fraudulent Conveyance Act \$ 144, and $\$ 67(d)$ of the Bankruptcy Act, 52 Stat. 877 (1938), 11 U.S.C. 107 (1952), made retention of possession by vendor, grantor or mortgagor subject to attack by his creditors. Twyne's Case, 3 Co. Rep. 80b (1601). In Clow v. Woods, 5 S. \& R. 275 (Pa. 1819) (mortgage of goods in process), Duncan, J., stated: "[B]y the principles of the common law, and the settled construction of the statutes of Elizabeth, to a mortgage of chattels delivery is necessary; that every such mortgage, 
regarded as likely subjects for fraud upon the borrower's general creditors, who would be unaware of any change in ownership and might advance credit in reliance upon the assignor's possession. ${ }^{86}$ Many chattel security transactions were avoided because of just such lack of notice. With the passage of recordation statutes governing chattel security transactions, ostensible ownershipcontinued possession despite transfer-no longer presents a basis for avoiding these security arrangements. ${ }^{87}$ While the doctrine of ostensible ownership as such is totally inapplicable to transfers of intangibles, ${ }^{88}$ the fears giving rise to that doctrine have pervaded the intangible area; delivery of a written assignment between the parties has been viewed as insufficient notice to prevent perpetration of fraud upon the assignor's general creditors. ${ }^{89}$ Therefore, additional evidentiary acts have been required to effect a transfer of an intangible.

Perfection assumes varying forms in various jurisdictions. ${ }^{90}$ If the assigned

when the parties stand in the relation of debtor and creditor, unaccompanied by such possession as the subject matter is capable of, is fraudulent and void against all other creditors, whether the debts were contracted antecedently or subsequently to the mortgage."

86. 1 GLENN $\$ 341$; Robinson v. Elliott, 89 U.S. (22 Wall.) 513 (1874) (creditor does not even have to prove that he extended credit in reliance upon ostensible ownership of property in a now insolvent debtor's possession). Accord, Casey v. Cavaroc, 96 U.S. 467 (1877).

87. See Glenn, The Chattel Mortgage as a Statutory Security, 25 VA. L. Rev. 316, 33839 (1939); Note, 66 YaLE L.J. 922 (1957) (trust receipt).

88. See Merillat v. Hensey, 221 U.S. 333 (1911) (since assignment of a chose in action need not have been recorded, no way in which constructive notice might be given) ; Stackhouse v. Holden, 66 App. Div. 423, 427, 73 N.Y. Supp. 203, 205 (4th Dep't 1901): "The rules pertaining to a change of possession of goods and chattels upon sale thereof, or to the filing of a lien thereon, and the dominion required to be exercised by a purchaser, mortgagee, or pledgee of tangible property, cannot be applied to sale or pledge of indebtedness, intangible of itself, only the evidence of which, if in writing, is perceptible; the conditions are not the same, and the rules of law applicable to transfers of the two classes of property differ; as to one, the possession of which is evidence of ownership, the dealings must be open, visible and public, while as to the other the business may be, and usually is, private." See also In re Hub Carpet Co., 282 Fed. 12, 16 (2d Cir. 1922), rev'd sub nom. Benedict v. Ratner, 268 U.S. 353 (1925): "This distinction has developed historically, but a further reason for the exclusion of choses in action from the rule of reputed ownership is that courts in their decisions have been reflective of the course of business in the commercial world."

89. In re Cotton Manufacturers' Sales Co., 209 Fed. 629 (E.D. Pa. 1913); Benedict v. Ratner, 268 U.S. 353 (1925) ; see Comment, 44 YaLE L.J. 639, 645 (1935). Compare Cohen \& Gerber, Mortgages of Accounts Receivable, 29 GEo. L.J. 555 (1941), with 2 GLENN §§ 530, 533.

90. The jurisdictional variation as to the effect of perfection with respect to different classes of claimants is made part of the Bankruptcy Act by means of $\$ 60$ (a) (2) which incorporates state law. While the general rule governing assignment holds, "an assignment of a contract right is operative to extinguish the right of the assignor and to create a like right in the assignee," 4 CORBIN $\$ 902$, varying state common-law rules on creation of a legal assignment, notes 26,27 supra, and priority between successive assignees, notes 36,37 supra, as well as those defining the extent to which existing and subsequent creditors may attack their debtor's transactions, 2 GLENN $\$ \S 316-40$, result in different treatment 
rights are to accounts receivable, a statutory scheme is generally applicable. ${ }^{91}$ These statutes usually provide for perfection by recordation of the assignment..$^{92}$ One form of recordation-intention filing-allows the filing of a notice of intention to assign prior to a contractual assignment; when the agreement is actually formulated, the transfer is perfected.93 Alternatively, filing may be subsequent to completion of the assignment contract. ${ }^{94}$ Under these circumstances, most states will accord the assignment full effect only from the date of recordation. ${ }^{95} \mathrm{~A}$ few states provide, however, that the assignment will date from execution of the written agreement if recorded within a specified

of the same transaction when tested in various states. Passage of statutes regulating the assignment of accounts receivable, which may be applicable as well to assignment of contract rights, see note 99 infra, further exaggerate the variation in legal consequences, see, e.g., Comment, 67 Yale L.J. 402 (1958).

91. Ibid. The ten states still governed by the common law are Delaware, Mississippi, Montana, Nevada, New Jersey, New Mexico, New York, Tennessee, West Virginia and Wyoming. Of these, the common law of New Jersey, Moorestown Trust Co. v. Buzby, 109 N.J. Eq. 409, 157 Atl. 663 (Ch. 1931) ; New York, Williams v. Ingersoll, 89 N.Y. 508 (1882); Superior Brassiere Co. v. Zimetbaum, 214 App. Div. 525, 212 N.Y. Supp. 473 (1st Dep't 1925); cf. N.Y. PrRs. Prop. LAW \& 45; West Virginia, Fidelity Mut. Life Ins. Co. v. City Nat'1 Bank, 95 F. Supp. 276 (N.D.W. Va. 1950) ; and Montana, General Elec. Co. v. Black, 19 Mont. 110, 47 Pac. 639 (1897), appears to achieve the same result as validation statutes-the first assignee is given priority over a subsequent assignee, regardless of notification of the obligor. Wyoming may adhere by case law to the notification requirement for perfection against a subsequent assignee who notifies the obligor. Cody Finance Co. v. Leggett, 116 F. Supp. 700 (D. Wyo. 1953) (second assignee preferred over first assignee; but first assignment may have been void because of retention of dominion and control by the borrower). Mississippi requires notification for perfection of an assignment against a subsequent assignee, Canton Exchange Bank v. Yazoo County, 144 Miss. 579, 109 So. 1 (1926), as does Tennessee, Naill and Naill v. Blackwell, 164 Tenn. 615, 51 S.W.2d 835 (1932).

92. Twenty-three states now provide for recordation of accounts receivable financing transactions. Comment, 67 Y ALE L.J. 402, 410-11 n.33 (1958); Kentucky recently adopted the Uniform Commercial Code.

93. Ibid. A typical notice of assignment of accounts receivable reads:

Date.

.has assigned or intends to assign, or has assigned and intends to assign one or more accounts receivable to

Assignor

Address

Mo. Stat. Ann. § 410.010 (Supp. 1957).

\section{Assignee}

Address

94. Comment, 67 Yale L.J. 402, 410-11 n.33 (1958).

Ohio demands recording prior to or contemporaneous with assignment. Washington, Hawaii and California, which provide a time period after assignment in which filing must take place, would invalidate late-filed assignments against third parties-later assignees or creditors. Cf. Menick v. Carson, 96 F. Supp. 817, 819 (S.D. Cal. 1951).

95. See, e.g., Idaho Code Ann. \$ 64-904 (Supp. 1957); Tex. Rev. Civ. Stat. Ann. art. 260-6 (Supp. 1957) ; Utar Code ANN. § 9-3-4 (Supp. 1957); Comment, 67 Yale L.J. 402,413 n.39 (1958). 
period. ${ }^{96}$ In contrast to the more prevalent recordation procedures, a minority of jurisdictions with statutory provisions require no act of perfection subsequent to the written assignment. ${ }^{97}$ Where recordation statutes are applicable broadly to all varieties of contracts, perfection of assigned long-term contracts will, of course, parallel perfection of accounts receivable. ${ }^{98}$ But in many states, statutes governing accounts receivable are inapplicable to other forms of contract rights. ${ }^{99}$ In these jurisdictions, and in those which have no statutory provision for perfection whatever, assignments must be perfected according to the common law. The common-law rule predominantly applicable holds an assignment complete from the time of written contract and requires no further objective act for perfection. ${ }^{100}$ A few jurisdictions, however, require that notification be given the obligor, at least if the assignment is to be valid as against a subsequent assignee who notifies. ${ }^{101}$

96. Cat. Civ. Code $\$ 3018$; N.C. Gen. Stat. $\$ 44-\$ 0$ (b) (Supp. 1955); Wash. Rev. CODE $\$ 63.16 .030$ (Supp. 1957).

97. Comment, 67 Yale L.J. 402, 410 n.32 (1958); see Koessler, Assignment of Accounts Receivable, 33 CALIF. L. Rev. 40, 108-11 (1945) (comparing merits of recordation and validation statute proposals; deciding in favor of validation statutes).

98. Sections 9-106, 9-201, 9-204(1), (3), 9-402 of the Uniform Commercial Code, read in conjunction, would apparently permit filing to perfect security interests not only in "accounts" and "contract rights" but also in general intangibles. See also $\$ 9-306$, as to the possibility of a secured party's lien on proceeds arising from the assignor's disposition of such collateral.

Most recordation and validation statutes include in their protection "accounts," which are generally defined as rights to payment existing under an open account and "contract rights"-rights to future payment under an executory contract. E.g., Colo., Fla., Idaho, III., N.C., Ohio, Okla., Utah, Vt. See Comment, 67 Yale L.J. 402, 416 n.44 (195\$), interpreting statutory coverage of future acquired rights to payments. A minority of statutes clearly protect such future rights. UNIFORM COMMERCtal CODE $\$ 9-204(3)$ (Ky. Mass., Pa.), Iowa, Mich., Tex.

99. The definition of an assignment and of an account receivable vary. For example, sums due under a construction contract are expressly excluded from the Alabama, ALA. Code tit. 39, $\$ 207$ (Supp. 1955) ; California, CAL. Civ. Code $\$ 3017$; Georgia, GA. Code Ann. \$ 85-1806 (1955); Iowa, Iowa Code Ans. \$ 539.12 (Supp. 1957) ; Nebraska, Neb. Rev. Stat. \$ 69-601 (Supp. 1955); and North Carolina, N.C. Gen. Stat. \$ 44-77 (Supp. 1955), statutes. Nebraska also excludes amounts due from preharvest sale by a grower of farm crops.

The usual definition of accounts receivable is rights to present or future payments under an existing contract. Comment, 67 Y ALE L.J. 402,416 n.44 (1958). This would exclude assignments for security of contractual rights to leases, licenses, copyrights and similar intangibles from the scope of the statutes. Also excluded would be rights to render and receive performance.

100. This rule assumes a right capable of present conveyance; under the common law of most jurisdictions, a future right is not so capable. See note 27 supra. No/required form was postulated; intent to effect a present transfer, expressed either orally or in writing, was sufficient. Restatement, Contracts $\$ 157$ (1932); Christmas v. Russell, 81 U.S. (14 Wall.) 69, 84 (1871) (held no assignment had been intended). Validation statutes, subsequently enacted, adhere to the majority common-law rule. REPORT 167.

101. See note 91 supra. In addition, Missouri and North Carolina statutes permit notification of the account debtor as an alternative method of perfection to recordation; Georgia 
In the few states which allow legal assignment of future rights, what are generally considered equitable interests may be legally perfected; a valid legal assignment is perfected in future rights in a manner identical to perfection of an assignment of an existing right. ${ }^{102}$ However, where future rights are incapable of legal assignment under the applicable statute, a previous equitable assignment of such rights will not determine the time of perfection once the assigned res assumes legal existence. When the rights mature, the statutory procedures may have to be followed to obtain the desired protection. And the date of these later acts would establish the time of perfection. ${ }^{103}$ In common-law jurisdictions and in those states governed by

implies that notification would be an acceptable alternative. See Comment, 67 YALE L.J. 402, 415 n.42 (1958). See also Restatenent, Contracts $\& 167$ (1932); 4 CoRbin $\$ 894$ (collecting cases). For statutory provisions protecting the obligor, see Comment, 67 YaLE L.J. 402,418 n.46 (1958).

102. See note 98 supra. In United States v. R. F. Ball Constr. Co., 355 U.S. 587 (1958), reversing R. F. Ball Constr. Co. v. Jacobs, 140 F. Supp. 60 (W.D. Tex. 1956), a government tax lien filed subsequent to an unrecorded assignment of rights to future payments under an existing contract prevailed over the assignee's interest. Interpreting Int. Rev. Code of 1939, § 3672(a), 53 Stat. 449, as amended, 56 Stat. 957 (1942) (now Int. Rev. CODE of 1954, $\S 6323(a)$ ), the majority, in a per curiam opinion, determined that the statutory grant of priority to mortgage liens, a category found to embrace the assignee's security interest, was inapplicable since the interest was inchoate. Mr. Justice Whittaker dissented on the ground that assignments of future rights under existing contracts were legally valid and accordingly should not be so classified. However, the majority most likely did not intend to challenge the assignability of such rights. As the district court observed, the assignment had not been recorded. $140 \mathrm{~F}$. Supp. at 65 . And whatever the disabilities attending unrecorded security interests under state law, federal law controls the inchoate classification under $\$ 3672$. United States v. Acri, 348 U.S. 211 (1955); United States v. E. Regensburg \& Sons, 124 F. Supp. 687 (S.D.N.Y. 1954). Two previous decisions considering validity of assignments against government tax liens filed under $\$$ 3672 (a) had upheld even an equitable assignment, National Refining Co. v. United States, 160 F.2d 951 (Sth Cir. 1947), on the theory that the assignee for value was a purchaser, $c$ f. Grossman v. City of New York, 188 Misc. 256, 66 N.Y.S.2d 363 (Sup. Ct. 1946).

However, once the assignee is analogized to the mortgagee mentioned in $\$ 3672(a)$, the analogy drawn by the Ball majority, a holding that an unrecorded interest does not prevail over a filed federal tax lien conforms to prior decisions. Hart v. United States, 207 F.2d $\$ 13$ (\&th Cir. 1953) ; United States v. Levin, 128 F. Supp. 465 (D. Md. 1955). So viewed, the dissent's objection that the decision overlooked the recognized assignability of future rights under existing contracts seems attributable more to the brevity than the thrust of the majority opinion.

103. The majority of recordation statutes provide than an assignment is perfected when filed or when made, whichever is later. See Comment, 67 Y ALE L.J. 402, 413 n.39 (1958). Even when notice of intention to finance is filed concurrent with the making of an equitable assignment, the coincidence of these dates would seem irrelevant in jurisdictions which, by limiting protection to rights assigned under an existing contract, do not appear to give substantive effect to the admittedly allowable filing of equitable assignments. Ariz., Cal., Colo., Conn., Fla., Ind., Idaho, I1l., N.C., N.H., Ohio, Okla., Utah, Va., Wash., Wis., Hawaii. Id. at $416 \mathrm{n} .44$. Whether the making of a further assignment or identification is necessary when the contract under which rights are to arise comes into existence, or whether an automatic accrual doctrine will be followed, is unclear. See H. S. Mann Corp. v. Moody, 144 Cal. App. 2d 310, 301 P.2d 28 (1956) (common-law protection of 
validation statutes-statutes holding an assignment perfected when written 104_an equitable assignment will be perfected either when the assigned res comes into existence or, if a further objective act is required, upon reconveyance of the nascent right.

Although rarely required for perfection of a legal assignment, notice should be given to the obligor whenever practicable. Should the obligor acquiesce in the assignment, the secured party has some assurance of reçeipt of the assigned performance. ${ }^{105}$ Moreover, he will have performed an objective act demonstrative of a present transfer of the right and removed from the assignor the power to create subsequent assignees capable of notifying and receiving the assigned performance from the obligor. Otherwise, the obligor without notice will be discharged by rendering performance to the assignor, his creditors or some subsequent assignee. ${ }^{100}$ Under such circumstances, the assignee will generally have a right of recovery over against the collecting party. ${ }^{107}$ In recordation states, for example, the statutes often specifically charge all persons collecting from the obligor with constructive notice

after-acquired rights continued). In any event, filing prior to the existence of the rights would not set the time of perfection. For discussion of the common-law doctrines as to perfection of an equitable assignment of future rights, see notes 26,27 supra.

Regardless of the doctrine applied with regard to creditors, constructive notice provided by filing may not protect against subsequent assignees who filed after the right had come into existence. While protection would be afforded by the statutes of Arizona, Idaho, Louisiana, North Dakota, Hawaii, Puerto Rico and Utah, Comment, 67 YALE L.I. 402, 412 n.37 (1958), the result under the Colorado, Florida, Kansas, Nebraska, Oklahoma and Vermont statutes is less clear. Under these statutes, the assignee who records takes prior even to assignments of which he has written notice. Id. at 412 n.35. Notice of assignment which is not of an existing right and therefore not entitled to the protection of the statute would accordingly not seem to upset his priority. Cf. Oklahoma Oxygen Co. v. Citizens State Bank, 274 P.2d 372 (Okla. 1954) (after-acquired accounts not protected by filing, but good against attacking creditors).

104. For a list of states with validation statutes, see Comment, 67 Y ALE L.J. 402, 410 n.32 (1958).

105. Notice to the obligor will bar defenses, set-offs or counterclaims arising subsequent to the obligor's receipt of notice, which otherwise would be available against the assignee. Ertel v. McCloskey, 167 Pa. Super. 120, 74 A.2d 652 (1950) ; Fera v. Wickham, 135 N.Y. 223 (1892); Wood v. The Mayor, 73 N.Y. 556 (1878); 2 Williston, Contracts $\$ 432$ (rev. ed. 1936).

106. Kniffin v. State, 283 N.Y. 317, 28 N.E.2d 853 (1940) (performance rendered assignor after notice; obligor not discharged); see Koessler, Assignment of Accounts Receivable, 33 CAIIF. L. REv. 40, 63 (1945); 4 CORBIN $\S 902$. Of course, notification is of no use to an equitable assignee as against a creditor intervening before perfection of his interest. REPORT 382.

107. Seamon v. Federated Films, Inc., 142 N.Y.S.2d 324 (N.Y. City Ct. 1955) ; Mercantile Ins. Co. v. Jackson, 40 Wash. 2d 233, 242 P.2d 503 (1952). Compare Smith v. Harris, 127 Cal. App. 2d 311, 273 P.2d 835 (1954) (assignee of account prevailed over creditor of assignor, although he had not recorded, since his assignment arose in another state and he had notified the obligor), with Menick v. Carson, 96 F. Supp. 817 (S.D. Cal. 1951) (simple contract creditor who extended credit before filing allowed to recover proceeds already collected by the assignee). See also Dupree v. Quinn, 290 S.W.2d 329 (Tex. 
of a prior recorded assignment and make them constructive trustees for the assignee. ${ }^{108}$ Nevertheless, a suit to enforce the constructive trust, with its accompanying problems of trial and tracing, is obviously undesirable. ${ }^{109}$ And in a few jurisdictions, even this recourse is denied the nonnotifying assignee, who retains only his contractual claim against the assignor. ${ }^{110}$ Therefore, despite its nondirectory nature, notification presents a practical method of protecting security interests.

Even compliance with statutory requisites for perfection may not insure the continued validity of a security interest. ${ }^{111}$ However, if the method of perfection satisfies an evidentiary test as to the time of assignment and effectively imports notice to third parties that the specific property has been transferred, absolute validity should be accorded upon such compliance. Validation statutes, declarative of the common law of most jurisdictions, do not satisfactorily meet these two tests which would insure that perfection served a function analogous to change in possession of tangibles. ${ }^{112}$ On the other hand, recordation, the

Civ. App. 1956) (despite notification of the obligor, judgment creditor could prevail over assignee who left dominion and control of assigned accounts in borrower).

Subsequent assignees prevailed over prior assignees in Judson v. Corcoran, 58 U.S. (17 How.) 611 (1854) ; Cody Finance Co. v. Leggett, 116 F. Supp. 700 (D. Wyo. 1953) (subsequent assignee preferred over prior assignee of existing and future accounts who permitted assignor to collect proceeds and substitute accounts). But see Fairbanks v. Sargent, 117 N.Y. 320, 22 N.E. 1039 (1889).

108. E.g., Cal. Civ. Code § 3025; Idaeo Code Ann. § 64-901 (Supp. 1957) ; Mrce. Stat. Ann. \$ 19.845 (Supp. 1957) ; Mo. Stat. Ann. \$ 410.040 (Supp. 1957); N.C. Gen. Stat. § 44-82 (Supp. 1955); Tex. Rev. Civ. Stat. Ann. art. 260-1, § 7 (Supp. 1957).

109. See SCOTt, Trusts $\$ \S 15$ n.5, 515, 517.3, 522 (1956) ; 4 Collier $\Uparrow 70.25$, at 1141.

110. Rabinowitz v. People's Nat'l Bank, 235 Mass. 102, 126 N.E. 289 (1920), states this rule, adopted by Restatenrent, Contracts $\$ 173$ (1932). Massachusetts no longer adheres to this rule since its adoption of the Uniform Comnercial Code. See Koessler, Assigniment of Accounts Receivable, 33 CALIF. L. REv. 40, 65, 71 (1945), indicating the possibility that many states would, at least under certain equitable exceptions, follow this doctrine. See also $i d$. at $86 \mathrm{n} .137$ indicating that validation statutes may import this rule into the statutory scheme applicable to accounts receivable.

111. Aside from the Uniform Fraudulent Conveyance Act, applicable in twenty states, and common-law doctrines of fraudulent transfers, 1 GLENN $\S 62$, the doctrine enunciated by Benedict v. Ratner, 268 U.S. 353 (1925), see notes 119-22 infra and accompanying text, is available in a large number of jurisdictions to invalidate an otherwise perfected transfer. The adoption of the Uniform Fraudulent Conveyance Act by a state does not overrule Benedict. Lee v. State Bank \& Trust Co., 54 F.2d 518 (2d Cir. 1931) ; cf. American S.S. Co. v. Wickwire Spencer Steel Co., 42 F.2d 886 (W.D.N.Y. 1930), aff'd per curiam, 49 F.2d 766 (2d Cir. 1931). Moreover, since Benedict applies to transfers which have been recorded, Brown v. Leo, 12 F.2d 350 (2d Cir. 1926) (mortgage on real estate and stock of goods entirely void due to borrower's dominion over proceeds of sale of goods), the recordation and validation statutes will not limit its effect except in so far as it is expressly overruled by statute. Comment, 67 YaLE L.J. 402,417 n.45 (1958), lists eight states renouncing Benedict in whole, by statute; seventeen which have statutes renouncing Benedict in regard to borrower's dominion over returned goods. See notes 119-52 infra and accompanying text.

112. See Report 517 describing the fourteen validation statutes. Koessler, Assignment of Accounts Receivable, 33 CALIF. L. REv. 40, 86-91 (1945). Validation statutes 
currently favored method of perfection, can, if adequately administered, fulfill these standards. Thus, filing simultaneous with or subsequent to the writing of an assignment does provide an evidentiary test as to the time of transfer. ${ }^{113}$ Since the records of assignment are available to the public, moreover, a prospective creditor is theoretically capable of determining the true status of the property interest. ${ }^{114}$

Unfortunately, the ordinary statutory procedures governing recordation of accounts receivable financing may not fully satisfy these tests. Because it occurs prior to the writing of an assignment, intention filing permits back-dating of subsequent assignment transactions. ${ }^{115}$ Again, notice of intention to finance provides only information that financing is expected, without necessarily specifying the extent of the financing and the property involved.110 But intention filing in the accounts receivable context was adopted as the only practical method of recording multiple short-term transactions. ${ }^{117}$ In contrast, long-term contract rights could practically be recorded individually. Nevertheless, the confusion likely to result from a dual system of recordation, one for long-term contract rights and another for accounts receivable, militates against a separate statutory method of perfection for the former, especially since many contract

make no attempt to give notice to third parties and, apart from the usual requirement that the assignment be in writing to obtain statutory protection, afford no test of date of assignment to prevent back-dating or other fraud.

113. Yet all states allow filing prior to assignment, presumably to avoid a "race to the courthouse steps" which would be required under the decision in Constance v. Harvey, 215 F.2d 571 (2d Cir. 1954) (relying on $\S 70$ (c) of the Bankruptcy Act, 52 Stat. 88 (1938), 11 U.S.C. $\$ 110$ (c) (1952), as interpreted in MOORE, DebToRs' aNd CredrTors' RIGHTS 656 (1955)).

114. See Comment, 67 Yale L.J. 402, 410-11 n.33 (1958); Note, 4 U.C.L.A.L. Rev. 471 (1957); Cohen \& Gerber, Mortgages of Accounts Receivable, 29 Geo. L.J. 555, 575 (1941); Ballantine, Purchase for Value and Estoppel, 6 MrNn. L. Rev. 87, 91 (1922). But see Comment, 44 YaLe L.J. 639, 651 (1935).

115. Since filing protects from the date of recording or from the making of the assignment, whichever is later, the risk of back-dating of the assignment which is feared by courts, Cohen \& Gerber, supra note 114, at 575; Note, 101 U. P. L. REv. 392, 401 (1952), is not substantially diminished. See Mica. Star. ANN. $\$ 19-\$ 42$ (Supp. 1955) which is designed to prevent back-dating of assignments but ignores the possibility of back-dating of underlying assignment agreements.

116. But see, e.g., C C AL. CIv. CoDE $\S 3026$ : "It shall be the duty of any assignee who has filed a presently effective and uncancelled assignment to furnish to any person such information relative to assignments of accounts as the assignor may in writing direct." Mo. ANv. Stat. $\$ 410.010$ (Supp. 1957): "In the event such detailed information is not filed of record every assignor who shall join in executing a notice as above provided shall, upon written demand of a bona fide creditor of said assignor, supply to said creditor full information as to the transaction represented by the said notice."

117. REPORT 356: "The rapid collection of assigned accounts and substitution of new accounts as security precludes any specification of particular accounts as subject matter in the recording of assignments, and thus any recording or public notice would operate as notice of the assignor's practice of assigning his accounts, rather than a notice of lien on particular assets." 
rights may not be readily classifiable in either category. ${ }^{118}$ Furthermore, the very elements which make long-term contract rights capable of individual recordation also make intention filing an adequate recordation procedure; since long-term contracts are single and unique, interested creditors with knowledge gained from the filing records may feasibly inquire to determine the exact status of the assigned rights. Therefore, while present recordation statutes may not fully conform to the optimum standards of perfection, in the interests of certainty and simplicity they should be legislatively extended or judicially construed to include long-term contract rights financing.

\section{Contract Rights and Benedict v. Ratner}

Even though all the technical provisions requisite to creation of a perfected assignment have been satisfied, conduct of a lender subsequent to perfection may invalidate the assignment. In many jurisdictions, a lender will be denied his security if he allows the borrower to exercise dominion and control over rights allegedly assigned. ${ }^{119}$ Such a course of conduct is held to be fraudulent in law as to other creditors. ${ }^{120}$ And if the assignment is a fraudulent transfer, it may be avoided within or without bankruptcy. ${ }^{121}$ Enunciated in the landmark

118. See notes 98,99 supra.

119. Conduct which amounts to such dominion and control includes: assignor permitted to retain proceeds so long as he is not in default on his loan, In re Nizolek Furniture \& Carpet Co., 71 F. Supp. 1012 (D.N.J. 1947), aff'd, 165 F.2d 78\& (3d Cir. 1948) ; assignor permitted to use funds in his business, Guinzburg v. D. A. Schulte, Inc., 91 F.2d 733 (2d Cir. 1937) ; assignee collected proceeds but deposited surplus over amount due on loan installment in bank account upon which borrower was allowed to draw at will, Dupree v. Quinn, 290 S.W.2d 329 (Tex. Civ. App. 1956); assignor commingled assigned funds with his own, Markovitz v. Taylor, 94 F.2d 782 (3d Cir. 1938).

But analogous situations have passed the test of dominion and control. See cases collected at notes 138, 140 infra. Benedict stated that where dominion was exercised concurrently with substitution of accounts of equal value, it would be permissible, citing Young v. Upson, 115 Fed. 192 (S.D.N.Y. 1902); Clark v. Iselin, 88 U.S. (21 Wall.) 360 (1875). Such arrangements have been upheld in In re M. J. Hoey \& Co., 19 F.2d 764 (2d Cir.), cert. denicd, 275 U.S. 550 (1927).

For discussion of the test of dominion and control, see 24 N.Y.U.L.Q. REv. 598 (1949); REPORT.

120. Benedict v. Ratner, 268 U.S. 353, 360 (1925): "Under the law of New York a transfer of property as security which reserves to the transferor the right to dispose of the same, or to apply the proceeds thereof, for his own uses is, as to creditors, fraudulent in law and void." REPORT 459. See also 2 GLENN $§ \S 530,543,584$.

121. Bankruptcy Act $\S \S 60,70$ (c), (e), 64 STAT. 25, 26 (1950), 11 U.S.C. $\S 95$, 110 (c), (e) (1952), enable the trustee in bankruptcy to attack transfers for security which could have been defeated by creditors under state law.

Actual intent of the immediate parties to the assignment is not considered relevant. Thus, in Bcnedict, despite a finding below that there was no actual fraud, In re Hub Carpet Co., $2 \$ 2$ Fed. 12 (2d Cir. 1922), the assignment of accounts receivable was held fraudulent in law and the assignee's collections preferences recoverable by the trustee in bankruptcy. Lee v. State Bank \& Trust Co., 54 F.2d 518, 520 (2d Cir. 1931), stated: "Assignments invalidated by the rule of Benedict $v$. Ratner, are not conveyances of that character; in them it is quite immaterial that the assignor has no intent to hinder or defraud creditors." 
decision of Benedict $v$. Ratner, ${ }^{122}$ this attitude reflects principles the source of which, while purportedly the common law, is unclear. ${ }^{123}$

But see Chapman v. Emerson, 8 F.2d 353 (4th Cir. 1925) (absent intent to defraud, assignment held valid).

122. 268 U.S. 353 (1925). For discussions of the case, see REFORT 454; Cohen \& Gerber, supra note 114; Koessler, Assignnent of Accounts Receivable, 33 CALIF. L. Rev. 40 (1945) ; Note, 101 U. PA. L. Rev. 392 (1952) ; 24 N.Y.U.L.Q. REv. 598 (1949); 2 GLENN \& 592 .

See In re Samuel Kades, Inc., 18 F. Supp. 455, 457 (M.D. Pa. 1937) ; In re McCown, 31 F.2d 334, 336 (M.D. Pa. 1928), indicating that Benedict was a federal common-law rule rather than an application of state common law. As to the persuasiveness of Benedict as a rule of law after Erie R.R. v. Tompkins, 304 U.S. 64 (1938), see 4 CoLLIER $\{70.77$ nn.76 \& 79.

The validity of a security device which permits the borrower to retain dominion and control over assigned rights has been denied in New Jersey, Stulz-Sickles Co. v. Fredburn Constr. Co., 114 N.J. Eq. 475, 169 Atl. 27 (Ch. 1933) (assignment of moneys to come due on a construction contract) ; Pennsylvania, Markovitz v. Taylor, 94 F.2d 782 (3d Cir. 1938), affirming In re Fergusson Drug Co., 19 F. Supp. 206 (E.D. Pa. 1937) (but see Pa. Stat. Ann. tit. 12A, \& 9-205 (Supp. 1956)); Oregon, Chambers v. Hot Lake Sanatorium, 151 Ore. 20, 45 P.2d 1045 (1935); Washington, J. W. Fales Co. v. O. H. Seiple Co., 171 Wash. 630, 19 P.2d 118 (1933) (but see WAsh. Rev. Code $\$$ 63.16 .020 (Supp. 1957) abolishing the proscription of assignor retention of dominion and control in regard to accounts receivable arising under existing contracts); Wisconsin, Eiseman v. Curtis Companies, Inc., 231 Wis. 260, 285 N.W. 747 (1939). Benedict has been declared by federal bankruptcy courts to be the law of Maryland, Union Trust Co. v. Peck, 16 F.2d 986 (4th Cir. 1927), affirming In re Almond-Jones Co., 13 F.2d 152 (D. Md. 1926) ; In re Helfenbein, 32 F. Supp. 26 (D. Md. 1940) ; City Nat'l Bank v. Zorn, 68 F.2d 566 (5th Cir. 1934), and applied as the law of Missouri, McCluer v. Heim-Overly Realty Co., 71 F.2d 100 (8th Cir. 1934), and North Carolina, In re Joseph, 43 F.2d 252 (M.D.N.C. 1930). See also Guinzburg v. D. A. Schulte, Inc., 91 F.2d 733, 735 (2d Cir. 1937) (indicating that a majority of state common law is in accord).

States repudiating Benedict, in whole or in part, are listed in Comment, 67 YALE L.J. 402, 417 n.45 (1958). Express repudiation may be merely declaratory of the common law, as in Michigan, but may also be interpreted as a change in the state common law applicable only to those rights specifically covered in the statute. Thus, Texas, which by statute, Tex. Rev. Crv. Stat. Ann. art. 260-1 (Supp. 1957), rejects Benedict's application to returned goods, applied the rule of conclusive invalidity to retention of control by the assignor in Dupree v. Quinn, 290 S.W.2d 329 (Tex. Civ. App. 1956).

123. Early decisions lend some support to the idea that, at common law, an attempted assignment was nugatory if it did not remove from the assignor control over rights supposedly assigned. Thus, in Christmas v. Russell, 81 U.S. (14 Wall.) 69, 84 (1872), the Court stated: "The assignor must not retain any control over the fund-any authority to collect, or any power of revocation. If he do, it is fatal to the claim of the assignee." Cf. In re Cincinnati Iron Store Co., 167 Fed. 486, 488 (6th Cir. 1909): "The validity of the assignments of the payments under the construction contracts is assailed as being void as to creditors represented by the trustee: . . . second, for the reason that the assignor ... retained ... full dominion and control over the assigned claims . . ." However, the assignee prevailed.

Nevertheless, it is generally considered doubtful that the decision did actually represent, as it claimed, the law of New York. See Cohen \& Gerber, supra note 114, at 564 (discussing Stackhouse v. Holden, 66 App. Div. 423, 73 N.Y. Supp. 203 (4th Dep't 1901), which Benedict repudiated); REPORT 488; 2 GLENN \$ 592. 
Benedict arose out of an accounts receivable financing arrangement. However, the principles it established have broad application in the field of secured financing. ${ }^{124}$ Upon a theory of "conceptual repugnancy," any assignment which permits the borrower to retain control over the proceeds of assigned accounts is subject to invalidation. ${ }^{125}$ The intangible counterpart of ostensible ownership as applied to chattel security, conceptual repugnancy, or dominion retained, remains a doctrine of uncertain import. ${ }^{126}$ But whatever the exact meaning, the implications of Benedict persist and pervade the cases arising in the field of intangible security whether in or out of bankruptcy.

Under its broadest interpretation, Benedict would invalidate any transfer if rights in the assigned property could be subject to destruction by the assignor, acting individually or in conjunction with some third party. ${ }^{127}$ Such a reading

124. For example, Benedict is applied to: real estate mortgage coupled with a mortgage on chattels, Brown v. Leo, 12 F.2d 350 (2d Cir. 1926); chattel mortgage on inventory including accounts receivable, In re Steele, 122 F. Supp. 948 (E.D.N.C. 1954); trust receipts, 4 COLLIER $\int 70.58$; mortgages of fixtures and equipment, Arbury v. Kocher, 18 F.2d 58S (W.D.N.Y. 1927) ; pledge of securities, In re Prudence Co., 88 F.2d 420 (2d Cir. 1937).

125. In Brown v. Leo, supra note 124, at 351 (invalidating a real property and chattel mortgage which allowed the mortgagor to sell stock without accounting for proceeds), Hand, J., stated: "[T] he doctrine . . can only rest upon some supposed conceptual repugnancy between the mortgage and the reserved power, quite regardless of any evils which may result from their coupling."

126. Both Cohen \& Gerber, supra note 114 , at 560, and 2 GLENN $\$ 533$ suggest that ostensible ownership is the real basis for invalidating assignment arrangements, despite Benedict's declaration to the contrary. Secrecy has not been a necessary element for invalidation under Benedict. Brown v. Leo, 12 F.2d 350 (2d Cir. 1926); 24 N.Y.U.L.Q. Rev. 598, 599 (1949). Nevertheless, the principal objection of the courts to assignments is the presence of "secret liens." In re Lambert \& Braceland Co., 29 F.2d 758, 759 (E.D. Pa. 1928) ; J. W. Fales Co. v. O. H. Seiple Co., 171 Wash. 630, 641, 19 P.2d 118, 121 (1933) ; see Notes, 39 Harv. L. Rev. 253, 256 (1925), 38 Minn. L. Rev. 249 (1954) ; cf. 1 GleNN $\$ 343$ (c) ; In re New York, N.H. \& H.R.R., 25 F. Supp. 874 (D. Conn. 1938) (assignment to RFC well publicized; Benedict held inapplicable).

127. A primary example of the application of this interpretation is in the invalidation of assignments when the assignor maintains the power to deal freely with returned goods, either through reservation in the assignment or by conduct in which the assignee acquiesces. Lee v. State Bank \& Trust Co., 54 F.2d 518 (2d Cir. 1931) (while returned goods actually amounted to less than $11 / 4 \%$ of assigned accounts, entire assignment invalidated). This conduct is usually used as an example of the more restricted interpretation of Benedictimproper freedom in the assignor to deal with the proceeds of assigned rights. Zydney $v$. N.Y. Credit Men's Ass'n, 113 F.2d 986, 988 (2d Cir. 1940) ; Peterson v. National Discount Corp., 179 Wash. 108, 117, 35 P.2d 1097, 1101 (1934). However, as was indicated in Bloch v. Mill Factors Corp., 119 F.2d 536 (2d Cir. 1941), returned goods are not "proceeds" of accounts receivable.

When the effect of acceptance of returns is viewed as an instance of assignor power to alter the nature of assigned rights by rescinding or modifying the contract under which the rights arise, the broader effect of invalidating nonnotification assignments of executory contracts generally is discernible. See, e.g., Kolkman v. Manufacturers' Trust Co., 27 F.2d 659, 662 (2d Cir. 1928) ; Updike v. Manufacturers' Trust Co., 243 App. Div. 15, 275 N.Y. Supp. 716 (1st Dep't 1934) (discussing the application of Benedict when the obligor retains a right of contractual set-off). 
would have particular relevance to the assignment of rights in an executory contract. For until the assignor has fully performed, he can destroy the lender's security by agreeing with the obligor to a modification sufficiently material to change the nature of the rights identified in the assignment. Repudiation by the assignor or obligor would, of course, also negate the value of the assignment. ${ }^{128}$ In addition, since an obligor without notice is discharged by payment to any interested party, an assignor, by collecting and keeping the proceeds or by creating subsequent assignees, may undermine his assignee's security interest. ${ }^{129}$ The strict language of Benedict, therefore, would jeopardize an assignment of contract rights unless the obligor was immediately notified and the assignment contained a provision entitling the lender to assume or delegate performance of the contract at will. ${ }^{130}$ An assignment would be of questionable validity even under these conditions, since an assignor always retains some control over the assigned rights, not completely countered by an option of performance, in his ability to repudiate the underlying contract.

The narrower interpretation of Benedict normally relied upon by the courts would invalidate an assignment if the assignor were permitted to deal freely with proceeds of the rights transferred. When the lender fails to check the borrower's collection and remission of proceeds and is content to rely, as unsecured creditors do, on the borrower's honesty, a conclusive presumption arises that he had no real intention of maintaining a security interest. Therefore, despite an expressed intent to acquire security, the subsequent conduct is construed as a consensual abdication of the assignment. ${ }^{131}$ Legally obviating any intent to be secured, such conduct also destroys the equitable lien which normally accrues upon an ineffectual legal assignment. ${ }^{132}$ Thus, an assignee

128. See note 80 supra.

129. See note 106 supra; Southern Kraft Corp. v. Standard Capital Corp., 27 N.Y.S.2d 238 (Sup. Ct. 1941), aff'd, 264 App. Div. 753, 35 N.Y.S.2d 269 (1st Dep't 1942), referce's findings aff'd, 40 N.Y.S.2d 947 (Sup. Ct. 1943), aff'd, 268 App. Div. 959, 51 N.Y.S.2d 571 (1st Dep't 1944), aff'd, 294 N.Y. 937, 63 N.E.2d 121 (1945). The court here applied Benedict to an action for an accounting between assignees of the same account. But the prior assignment was upheld; the assignor was found not to have unfettered domain within the meaning of Benedict.

130. See text at note 71 supra. In Dupree v. Quinn, 290 S.W.2d 329 (Tex. Civ. App. 1956), even notification of the obligor failed to protect the assignee from application of Benedict, which invalidated the transaction at the instance of a judgment creditor of the assignor.

131. Mount v. Norfolk Sav. \& Loan Corp., 192 F.2d 286 (4th Cir. 1951) ; Lichtenberg v. Harvey, 57 F.2d 82 (2d Cir. 1932); Lee v. State Bank \& Trust Co., 54 F.2d 518 (2d Cir. 1931); 24 N.Y.U.L.Q. REv. 598, 603 (1949). For an example of policing followed by lenders to protect their security from Benedict attack, see In the Matter of the New Haven Clock \& Watch Co., Civil No. 24767, 2 d Cir., March 28, 1958.

132. 4 Collier If 70.77 , at 1392 ; see 24 N.Y.U.L.Q. Rev. 598, 600 (1949). In In re Hurley, 18 F.2d 363 (D. Minn. 1926), a bank, holding a pledge as collateral to bankrupt's note, permitted bankrupt to sell the collateral. Proceeds of sale, which were to be applied to the note, were retained by the bankrupt. The bank was held to have constituted the bankrupt its agent for sale; and the note could not be proved against the estate in bankruptcy. 
failing to maintain his security interest may be subordinated to a subsequent assignee controlling proceeds once the prior assignment may be considered nullified. ${ }^{133}$ Creditors would be entitled to attach and execute upon the purportedly assigned property. ${ }^{134}$ And not only does the trustee in bankruptcy have priority to the res residing with the obligor, but he may also collect proceeds which were actually conveyed to the assignee in advance of bankruptcy. ${ }^{135}$

Bcnedict, by requiring that the borrower be denied any control of assigned rights, has effectively forced the lender to acquire all receipts even though a stipulated proportion might better conform to the parties' desires. ${ }^{136}$ To obviate this requirement where the loan is of extended duration, resort has been made to a revolving loan agreement. Under this arrangement, each time assigned rights mature, the current loan is reduced and a new loan in amount equal to the reduction is allowed concurrent with a substitution of new rights. ${ }^{137}$ In this manner, the proportion of outstanding collateral and loan remains constant. Such a system, meeting the technical requirements of Benedict, has received judicial approval. ${ }^{138}$ Nevertheless, implicit in the scheme are just those practices which Benedict apparently was intended to overcome. Satisfactory evidence of continuing lender control over proceeds is not provided. And substitution of rights can involve the detriments of equitable assignment

133. See note 129 supra.

134. 4 COLIIER $\{70.77 \mathrm{nn} .1 \& 42$ (collecting cases) states that a majority of states would apply Benedict to permit creditors to attack assignment transactions. See also Dupree v. Quinn, 290 S.W.2d 329 (Tex. Civ. App. 1956), criticized in Note, 55 Mrcz. L. Rev. 874 (1957).

135. See 4 Collier II 70.77 n.42 (collecting cases).

136. Irving Trust Co. v. Finance Serv. Co., 63 F.2d 694 (2d Cir. 1933); Thole v. Delmonico Garage Co., 47 F. Supp. 601 (S.D.N.Y. 1942); Cohen \& Gerber, supra note 114 , at 566 n.35. But see In re Dulberg, 60 F.2d 601 (E.D.N.Y. 1932) ( $\$ 100$ a week to be paid to assignee, assignor to retain excess of collections; valid assignment) ; Doggett v. Chelsea Trust Co., 73 F.2d 614 (1st Cir. 1934) (assignor to collect and deposit all proceeds with assignee bank but could withdraw $35 \%$ for his own use). Dunham, Inventory and Accounts Receivable Financing, 62 HARv. L. REv. 588, 596 (1949), describes the complex mechanism set up to meet the borrower's need for working capital and evade Benedict requirements of application of all assigned proceeds to the loans they secure.

137. The full mechanics of this arrangement are described in detail in Note, $101 \mathrm{U}$. PA. L. Rev. 392, 393 (1952) ; 24 N.Y.U.L.Q. Rev. 598, 601 (1949); Kripke, Current Assets Financing as a Source of Long-Term Capital, 36 MINN. L. Rev. 506 (1952).

138. Benedict v. Ratner, 268 U.S. 353, 364 n.18 (1925), states: "If it is agreed that the transferor may use the original collateral for his own purposes upon the substitution of other of equal value, the transfer is not thereby invalidated." Second Nat'l Bank v. Phillips, 189 F.2d 115 (5th Cir. 1951) ; In re Pusey, Maynes, Breish Co., 122 F.2d 606 (3d Cir. 1941) ; cf. In re Bernard \& Katz, Inc., 38 F.2d 40, 44 (2d Cir. 1930) (court expressly left open question whether assignment of substituted accounts could be attacked as a voidable preference); In re De Luxe Oil Co., 36 F. Supp. 287 (D. Minn. 1940) (substitution not sufficient; proceeds were also required to be segregated in a special bank account); In re Borok, 50 F.2d 75 (2d Cir. 1931) (value of substituted accounts must bear relationship to originally assigned accounts). 
in permitting a borrower to "back-date" and "kite" his statement of identification. ${ }^{139}$

Moreover, courts following strict contract reasoning have upheld the conditional assignment, which also avoids rigid adherence to the Benedict requirement of lender control. ${ }^{140}$ Such an arrangement contemplates the creation of a legal assignment in an existing contract right, with the assignee to receive performance on the underlying contract only if a specified condition occurs. $^{141}$ The condition might be the borrower's default in repayment accord-

139. A borrower "kites" his assignments by raising their value, or falsifying accounts, in the statements he submits to the lender, thus conveying the impression that he is assigning accounts of greater value than those he actually possesses. He back-dates by changing the date on the statements of identification of accounts to the assignment, either to create the impression that a simultaneous substitution of new accounts for old has taken place or to place the assignment outside of the four-month preferential period of $\$ 60$ of the Bankruptcy Act, 64 Stat. 25 (1950), 11 U.S.C. § 96 (1952).

Note, 101 U. PA. L. REv. 392, 394 (1952), indicates that the reasonably prudent commercial factor forestalis the possibility of kiting by making a new loan against new assignments. Thus, the assignee receives proceeds of all accounts and "by investigating the checks the factor can discover whether the borrower has been supplying him with false invoices and hence actually assigning him nothing and repaying him with his own money." But see 24 N.Y.U.L.Q. REv. 598, 601 (1949) : "One such device is . . to permit substitution of collateral by allowing the assignor to use the proceeds of assigned accounts provided he substitutes therefor new accounts of equal value . . . . The substitution arrangement keeps the working capital of the assignor constant and adequate, and yet avoids the necessity of new loans on assignment of the new account." 4 CoLLIER $\{70.77$ n.56.

Back-dating of assignments would seem necessarily to involve collusion of assignor and assignee.

140. In re New York, N.H. \& H.R.R., 25 F. Supp. 874 (D. Conn. 1938) (conditional assignment, to take effect on the assignor's default on the underlying loan, of a future right conditional on the obligor receiving income in excess of carrying charges upheld in reorganization proceedings); In re Allied Products Co., 134 F.2d 725 (6th Cir. 1943) (assignment of payments due on a construction contract conditional upon bankrupt's default in its contractual performance); In re McCrory Stores Corp., 73 F.2d 270 (2d Cir. 1934) (lessor's lien on subrents, to take effect after lessee's default in rental payment, held valid against trustee in bankruptcy); Malone v. Bolstein, 151 F. Supp. 544 (N.D.N.Y. 1956), aff'd, 244 F.2d 954 (2d Cir. 1957) (assignment of payments due on milk delivery contract, to take effect on bankrupt's failure to deliver milk to his obligor; default occurred within four months of bankruptcy; assignment upheld against trustee's contention that payments were preferential). These cases declared Benedict inapplicable to invalidate the assignment. Contra, Guinzburg v. D. A. Schulte, Inc., 91 F.2d 733 (2d Cir. 1937) (criticized in 4 CoRBri $\$ 876 \mathrm{n} .31$ ) ; In re Capitaine, 31 F. Supp. 312 (E.D.N.Y. 1940) (obligor not to be notified of assignment until assignor defaulted in payments to lender; assignment void against trustee in bankruptcy); In re Nizolek Furniture \& Carpet Co., 71 F. Supp. 1012 (D.N.J. 1947), aff'd, 165 F.2d 788 (3d Cir. 1948) (assignor permitted control so long as he paid current loan obligations; invalid).

141. The assignment creates a present interest in the assignee, perfected as of the date of its making. See 4 ConBin $\$ 876$, at 513 : "Furthermore, the fact that the assignment is itself expressly made conditional on the assignor's default as to principal or interest on the loan does not invalidate the assignment."

Cohen \& Gerber, supra note 114 , at $568-69$, state that a conditional assignment creates no lien throughout the period during which the assignor retains dominion so that a lien 
ing to the terms of the loan agreement, his failure to maintain a specified ratio of current assets to current liabilities or some other external criterion. ${ }^{142}$ Where the condition is the borrower's insolvency, however, the assignment may be voidable by the trustee in bankruptcy under state fraudulent conveyance statutes as well as under the Bankruptcy Act; such a transfer, unlike one including conditions held permissible, may be deemed to be made in contemplation of bankruptcy and considered fraudulent as to general creditors. ${ }^{143}$ Still, the conditional assignment permits a lender to circumvent Benedict and maintain a valid assignment although the borrower retains control of the proceeds of his business for a protracted period. Since the borrower exerts dominion only until occurrence of the condition specified, his protracted dominion is not inconsistent with-nor repugnant to-the transfer of title which was assigned only conditionally. ${ }^{144}$ Valid security is obtained without the need for formalities entailed in a revolving loan agreement. Further, a well drawn conditional assignment avoids constant surveillance by the assignee while permitting the advantages of a legal assignment dating from execution of the written agreement.

The decision in Benedict has been justified as requiring the secured lender to earn his advantage by supervising the assignor's business practices. This thesis argues that any lender desiring the favorable status of secured creditor should be held to a stricter standard of conduct than that required of an un-

coming into existence at default would be likely to coincide with the four-month period before bankruptcy. But the lien is created at the time of the original legal assignment, not at the time of default. Therefore, even if the condition upon which the assignment is to take effect occurs within the four-month period, no preference results. Malone v. Bolstein, 151 F. Supp. 544 (N.D.N.Y. 1956).

The valid conditional assignment must be distinguished from one which permits the assignor to retain and use the proceeds but enables the assignee to revoke this authority at will. Such an assignment is presumably fraudulent under Benedict.

142. See cases cited note 140 supra.

143. Cohen \& Gerber, supra note 114 , at 569 , state that the transfer would be voidable by the trustee under $\S 60(\mathrm{~b})$ of the Bankruptcy Act if he demonstrates that the assignee had reasonable cause to believe the assignor insolvent at the time of default. Although $\S 60$ (b) would seem inapplicable if the original assignment is made outside of the fourmonth period, see note 141 supra, the trustee could avoid an agreement which conditioned security upon insolvency or bankruptcy as evidencing actual intent to hinder, delay and defraud other creditors, Bankruptcy Act, \& 67 (d), 66 STAT. 429 (1952), 11 U.S.C. $\$ 110$ (1952); Uniform Fraudulent Conveyance Act § 7; McLaughlin, Application of the Uniform Fraudulent Conveyance Act, 46 Harv. L. Rev. 404, $421 \mathrm{nn} .83$ \& 84 (1933) (collecting cases).

144. See, e.g., 4 CoRsin $\$ 876$, at 514 : "[A]n assignment of future installments of rent (or of moneys due in other kinds of transactions) that may fall due after a default by the assignor in his duty to the assignee is not an attempt to assign his rights and at the same time to retain 'dominion' over them .... No inherent contradiction or inconsistency is involved; the assignor is making no attempt to have his cake and eat it too. His rights to payments to be made prior to a specified future event he does not assign at all; his rights to payments accruing thereafter he assigns without any reservation whatever." 
secured creditor $;^{145}$ the security is earned by controlling the debtor's business conduct and checking any undue expansion of credit to the detriment of unsecured creditors unequipped to investigate the debtor's financial status. ${ }^{146}$ By calling in proceeds which have been assigned to him, the lender removes any inflated appearance of affluence resulting from possession of both loaned and assigned funds. However, even without the rigid standard of Benedict, a lender may be expected to supervise the conduct of his borrower to forestall dissipation of funds. ${ }^{147}$ And in contrast to the persistent regulation required by Benedict, voluntary policing avoids continual and expensive supervision over a long no-danger period while retaining the advantages of investigation during risk periods. Under a conditional assignment, for example, the lender will be especially assiduous to check compliance with the terms of the assignment since these terms were drawn to reveal increased credit risk. ${ }^{148}$ Moreover, policing aside, the need for imposing the requirements of Benedict to furnish notice of an assignment pales when recordation is both available and required. ${ }^{149}$

Benedict was decided before section 60(a) of the Bankruptcy Act was revised to remedy the same evil-the equitable assignment which, when legally perfected, related back to the original instrument. ${ }^{150}$ The doctrine of relation back enabled a lender secretly to secure the borrower's future acquisitions and, by apt description, receive an interest in potential property of far greater value than the loan. Allowing the borrower to dispose of the property at will, the lender would rely on future acquisitions to substantiate his secret lien in case of insolvency. The revised section $60(\mathrm{a})$ is designed to preclude equitable relation back before the four-month period; Benedict is no longer needed for recovery of such transfers in bankruptcy. ${ }^{151}$ Outside of bankruptcy, secret

145. See, e.g., 24 N.Y.U.L.Q. Rev. 598, 603-04 (1949) ; Dunham, Inventory and Accounts Receivable Financing, $62 \mathrm{H}_{\mathrm{ARV}}$. L. REV. 588, 593, 598 (1949).

146. See Silverman, Factoring as a Financing Device, 27 Harv. Bus. Rev. 594, 599 (1949); Kripke, supra note 137, at 513; Koessler, Assignment of Accounts Receivable, 33 Caltif. L. Rev. 40, 54, 59 (1945).

147. See Note, 101 U. PA. L. Rev. 392, 400-01 (1952) ; Comment, 67 YALE L.I. 402, 405 n.17 (1958).

148. See cases cited note 140 supra.

149. See Note, 101 U. PA. L. REv. 392, 401 (1952) ; Cohen \& Gerber, supra note 114, at 575 ; Dunham, supra note 145 , at 598 . See also note 111 supra; notes 113,114 supra and accompanying text.

150. See REPORT 85-90; 3 Collier If $60.37,60.38$; Matter of Ideal Mercantile Corp., 143 F. Supp. 810 (S.D.N.Y. 1956) (purported assignment of a fund not yet in existence not perfected under $\S 60$ (a) (2) of the Bankruptcy Act); notes $42-44$ supra.

151. Section 60 (a) (6) should avoid all secret transfers where recording was available. Nevertheless, Benedict has been held applicable to transfers despite compliance with applicable recording provisions, see Manchester Nat'1 Bank v. Roche, 186 F.2d 827 (1st Cir. 1951) (N.H. Factors' Lien Act subsequently amended to dispense with Bencdict, N.H. Laws 1951, c. 333, § 4, amending N.H. LAws 1943, c. 161, and N.H. LAws 1949, c. 156), or with validation statutes, Mount v. Norfolk Sav. \& Loan Corp., 192 F.2d 286 (4th Cir. 1951) (construing VA. Code ANs. $\$ \$ 11-5$ to -7 (1950), now amended by VA. Code ANs. 
transfers are subject to attack for noncompliance with recording statutes where applicable or as fraudulent conveyances. ${ }^{152}$ Accordingly, Benedict's blanket proscription of assignments is unnecessary since more selective tests are available for striking down fraudulent transactions.

\section{EXECUTORY RIGHTS IN BANKRUPTCY}

Section 70(b) of the Bankruptcy Act empowers the trustee to assume or reject an executory contract within sixty days after an adjudication in bankruptcy. ${ }^{153}$ The trustee is permitted to reject a contract on his own motion,

§ 11-6 (Supp. 1956)). Compare Wells v. Place, 92 F. Supp. 473 (N.D. Ohio 1950) (failure to record assignment did not give trustee right of invalidation under $\$ 70(\mathrm{e})$ of the Bankruptcy Act), with In re Nolan Motor Co., 25 F. Supp. 186 (D.D.C. 1938), aff'd sub nom. Universal Dealers Co. v. Cromelin, 109 F.2d 828 (D.C. Cir. 1939), cert. denied, 310 U.S. 641 (1940).

Where validation statutes or similar common law control the perfection of assignments, actual intent to hinder, delay and defraud other creditors should be ground for avoiding assignments in which bad faith was evident, as it apparently is in many Benedict cases. In fact, bad faith was evident in Benedict itself, even though the circuit court had found to the contrary below in In re Hub Carpet Co., 282 Fed. 12 (2d Cir. 1922). See Note, 55 Mrce. L. Rev. 874 (1957) ; Cohen \& Gerber, supra note 114, at 574. And a doctrine of estoppel based on considerations similar to ostensible ownership would be applicable. 1 GleNN $\$ 343 ; 4$ Collier $\uparrow 70.77$, at 1395; Note, 101 U. PA. L. Rev. 392, 401 (1952). Contra, Hanna, Some Unsolved Problems Under Section 60a of the Bankruptcy Act, 43 Cor.um. L. REv. 58,69 (1943).

152. As to availability of noncompliance with recording statutes to creditors to strike down assignments, see, c.g., Comment, 67 Yale L.J. 402, 412 n.37 (1958); Treadwell v. A. Kristoferson, Inc., 32 Wash. 2d 145, 200 P.2d 740 (1948) (statute required assignment to be in writing for statutory protection); Menick v. Carson, 96 F. Supp. 817, 819 (S.D. Cal. 1951) (late-filed assignment invalid against a creditor who extended credit at any time before filing and before collection of the account). But see Oklahoma Oxygen Co. v. Citizen's State Bank, 274 P.2d 372 (Okla. 1954).

See also Comment, 57 YALE L.J. 828, 850 (1948) ; Colbath v. Mechanicks Nat'l Bank, 96 N.H. 110, 70 A.2d 608 (1950) (abolishing Benedict as applied to inventory; Factors' Lien Act held to be exclusive); Second Nat'l Bank v. Phillips, 189 F.2d 115, 118 (5th Cir. 1951) (Texas filing statute which removes secrecy makes Benedict less necessary); Note, 55 Mrсн. L. REv. 874 (1957) (criticizing application of Benedict in Dupree v. Quinn, 290 S.W.2d 329 (Tex. Civ. App. 1956)). Contra, Brown v. Leo, 12 F.2d 350 (2d Cir. 1926); 2 GLENN $\$ 583$ a, at 1007; In re Joseph, 43 F.2d 252 (M.D.N.C. 1930).

Fraudulent transfers are voidable under various sections of the UNIFORM F FAUDULENT Conveyance ACT $\$ \$ 1-14$, as well as at common law in most jurisdictions if actual fraud is proved, see note 85 supra.

153. 52 Stat. 879 (1938), 11 U.S.C. $\S 110($ b) (1952). The section is largely declaratory of prior law. Central Trust Co. v. Chicago Auditorium Ass'n, 240 U.S. 581 (1916) (declaring that, trustee having elected not to assume concession contract, breach of the contract gave rise to a claim for damages provable in bankruptcy); 4 Collier $\{70.43$, at 1225 .

Section 70(b) provides that express covenants in leases denying the trustee the right to assume contracts will be recognized: "[A]n express covenant that an assignment by operation of law or the bankruptcy of a specified party thereto ... shall terminate the lease or give the other party an election to terminate the same shall be enforceable." 52 
and his inaction is tantamount to rejection..$^{154}$ But assumption of an executory contract requires affirmative action, and court approval may be necessary. ${ }^{155}$ Thus, if the borrower has assigned as security an executory contract right, or if the lender has been made beneficiary of an executory contract without receiving an independent right to render performance, the trustee may unilaterally destroy the security by rejecting the contract. ${ }^{156}$ And even though

STAT. 879 (1938), 11 U.S.C. $\$ 110$ (b) (1952). 4 COLLIER $\{70.43$, at 1235 , suggests that this rule should be broadly applicable to all contracts: "While this provision relates expressly only to leases, where the problem usually occurs, there seems to be no good reason why the same principles would not be applied with regard to executory contracts generally in a similar situation, particularly since the provision here quoted represents merely an adoption of prior case law." In Thompson v. Texas Mexican Ry., 328 U.S. 134 (1946), a provision in a fifty-year contract between two railways allowing termination by either on twelve months notice was effective against the trustee in reorganization.

154. 4 COLzIER If 70.43, at 1230, 1233; In re Pagliaro, 99 F. Supp. 548 (N.D. Cal. 1951), aff'd sub nom. Costello v. Golden, 196 F.2d 1017 (9th Cir. 1952) (trustee took no action to assume conditional sales contract within sixty days after the adjudication in bankruptcy; contract deemed rejected). But although the status of executory contracts is to be determined rapidly, In re Public Ledger, Inc., 63 F. Supp. 1008 (E.D. Pa. 1945), rev'd on other grontnds, 161 F.2d 762 (3d Cir. 1947), the bankruptcy court may extend the trustee's time for making his determination, In re Rochester Shipbldg. Corp., $32 \mathrm{~F}$. Supp. 98 (W.D.N.Y. 1940). See also $\$ 116(1)$ of the Bankruptcy Act, 52 STAT. 885 (1938), 11 U.S.C. \$ 516(1) (1952), which gives the judge power to permit rejection of contracts in chapter ten reorganizations.

155. Fletcher v. Surprise, 180 F.2d 669 (7th Cir. 1950) (appeal from turnover order in bankruptcy; trustee's failure affirmatively to assume leases in question within time allotted resulted in rejection); 4 CoLrIER $\llbracket 70.43$, at 1233, states: "The general rule that economy of administration calls for close, strict, and active control by the court of all administrative expenditure seems to lead to the conclusion that it is improper for a trustee to assume executory contracts on his own responsibility. ... [T] [Te proper procedure is for the trustee to apply to the court for an order authorizing him to assume the contract if this is what his judgment advises him is the proper course. The court should pass upon his application after notice to and a hearing of creditors and probably also the other party to the contract." In contrast to assumption, assignment by the trustee clearly requires court approval under $\S 70(\mathrm{~b})$.

156. In Central Trust Co. v. Chicago Auditorium Ass'n, 240 U.S. 581 (1916), the trustee's rejection was construed to be an anticipatory breach of contract. See Matter of New York Investors' Mut. Group, Inc., 143 F. Supp. 51 (S.D.N.Y. 1956), 43 VA. L. Rev. 253 (1957), in which the trustee's rejection of an executory contract for sale of real property was upheld despite the vendee's claim of an equitable property interest. If a vendee's equitable interest in property upon which he has paid a portion of the purchase price may be destroyed by the trustee in bankruptcy in the interest of efficient liquidation of the estate, and the trustee need only consider the interests of the estate, the equities of the secured party who has been assigned rights under the contract, conditioned upon his borrower's performance, are not likely to be upheld. The breach of contract arising from the trustee's rejection would be a defense of the obligor in any action by the assignee to recover assigned performance which had not been earned prior to the adjudication. See notes 153, 72 supra. See also In re Italian Cook Oil Corp., 190 F.2d 994 (3d Cir. 1951) (trustee who assumed contract and performed could not collect funds which bankrupt had validly assigned under the contract; court implies that, had the trustee rejected the contract, the assignee would have had no claim); Great American Indemnity Co. v. 
he is also empowered to assign performance under the contract to a third party, the trustee will frequently reject. ${ }^{157}$ Because an assignment remains in effect after assumption, performance by the estate will not benefit the general creditors to the extent of the assignee's security interest. ${ }^{158}$ If some services have been performed by the assignor, the most profitable course for the estate may be to reject the contract and collect in quantum meruit. ${ }^{\mathbf{1 5 9}}$ Moreover, in any bankruptcy proceeding, the primary stress is on prompt liquidation of the bankrupt estate. ${ }^{100}$ Thus, the presumption of bankruptcy policy and procedure is for rejection.

Nevertheless, the assignee may wish to assume the duty of performance under the contract to salvage his security. More important, assumption and assignment of the contract may significantly benefit the estate if the assignee is willing to perform. Such action will eliminate damages for breach since court approval of assumption and assignment operates to insulate the estate from any liability under the contract. ${ }^{161}$ It can also reduce the assignee's claim as a general

Allied Freightways, Inc., 325 Miass. 568, 91 N.E.2d 823 (1950) (receivers who assumed and performed an executory contract advanced the same contention, arguing that, had they not assumed, the assignee would have taken nothing by its assignment). But see Hurley v. Atchison, T. \& S.F. Ry., 213 U.S. 126 (1909) (railway advanced sums to bankrupt coal company to insure regular supply of coal to it; court declared the unmined coal equitably pledged to the railway and ordered the trustee to mine and deliver it).

157. The trustee has a duty to abandon unprofitable property. In re Watts, 19 F.2d 526 (E.D. La. 1927). The probability of extensive litigation is one ground of abandonment. Greenall v. Hersum, 220 Mass. 278, 107 N.E. 941 (1915) ; Oldmixon v. Severence, 119 App. Div. 821, 104 N.Y. Supp. 1042 (1st Dep't 1907). The best interests of the estate are the trustee's sole guide. Matter of New York Investors' Mut. Group, Inc., $143 \mathrm{~F}$. Supp. 51 (S.D.N.Y. 1956).

158. When the trustee adopts a contract, he takes it with all its burdens. Grief Bros. Cooperage Co. v. Mullinix, 264 Fed. 391 (8th Cir. 1920) (retention of benefits under contract necessitates adoption, requiring production and delivery of goods). Accord, I I r re De Long Furniture Co., 188 Fed. 686 (E.D. Pa. 1911). Since the trustee must render performance under an executory contract he adopts, and since an original assignee will receive the benefits of the contract, adoption of an executory contract under which corresponding rights have been validly assigned as security is unlikely to be profitable for the estate. See cases cited note 156 supra. Moreover, upon assumption of the contract, the bankrupt is discharged from contractual liability and is replaced by the trustee. Rosenblum v. Uber, 256 Fed. 584 (3d Cir. 1919); In re Scruggs, 205 Fed. 673 (S.D. Ala. 1913). Additionally, the estate must be in a financial position to accept these liabilities, which are a first charge on the estate. 4 CoLrIER $\int 70.43$, at 1233-34. Therefore, the trustee might find it most desirable for the estate to rescind the contract entirely, with consent of the other contracting party if possible. See Kenyon v. Mulert, 184 Fed. 825 (3d Cir. 1911).

159. Recovery in quantum meruit, unlike collection under the contract, would not inure to the assignee's benefit. See note 75 supra.

160. 4 CollieR If 70.42, at 1217. "The paramount purpose of bankruptcy administration and liquidation is to reduce the bankrupt's property to money as expeditiously as practicable . . ." 4 id. \ 70.43, at 1228.

161. Assumption of the contract by the trustee purges any anticipatory breach of contract based on the fact of bankruptcy itself. Columbia Products Corp. v. Coronation Diamonds, Inc., 276 App. Div. 1083, 95 N.Y.S.2d 898 (2d Dep't 1950), reversing 90 
creditor to the extent of profit he may obtain from performance. Therefore, unless rejection is clearly beneficial to the estate, the assignee should be entitled to assume the contract and complete performance. ${ }^{102}$ Assurance that the trustee will not follow a general policy of summary rejection could be obtained by reversing the general presumption that inaction is sufficient to void a contract when an assignee expresses willingness to perform and by requiring court approval of rejection under such circumstances.

\section{The Third-Party Beneficiary Technigue}

When the lender desires to insure the co-operation of the prospective obligor, a third-party beneficiary contract may superficially appear an advantageous means of security. Based on the theory that consideration need not pass to immediate parties, third-party beneficiary contracts arise when parties express an intent that performance by one of them be rendered to a third person. ${ }^{103}$ The third party obtains an independent right to performance even though he has given no consideration under the contract. Almost universally recognized and enforced, ${ }^{164}$ the third-party beneficiary contract creates such a right

N.Y.S.2d 762 (Sup. Ct. 1949) ; cf. In re Robertson, 41 F. Supp. 665 (W.D. Ark. 1941). Where damages for breach would be substantial, elimination of the claim, which is provable under $\$ 57(\mathrm{n})$ of the Bankruptcy. Act, 52 STAT. 867 (1938), 11 U.S.C. $\$ 93(\mathrm{n})$ (1952), might redound to the benefit of the general creditors.

And the required court approval of assignment insulates the estate from further liability on the contract. Bankruptcy Act, $\$ 70(\mathrm{~b}), 52$ STAT. 879 (1938), 11 U.S.C. $\$$ 110 (b) (1952).

162. This suggestion might reverse the usual presumption that the trustee may assume only contracts which are clearly profitable to the estate. 4 CoLLrer If 70.43, at 1233. Note, 43 VA. L. Rev. 253 (1957), suggests that the vendee's equities as well as those of the general creditor should be considered in deciding whether to reject a contract. Similarly, the equities of secured creditors might also be considered.

163. Lawrence v. Fox, 20 N.Y. 268 (1859), is the leading case in the creditorbeneficiary field. Holly owed Lawrence $\$ 300$. Fox induced Holly to lend him that sum, promising to pay Lawrence and discharge Holly's debt. Lawrence was a stranger to the agreement between Holly and Fox; he gave no consideration to Fox. Lawrence was allowed to sue Fox to recover the promised sum. This case is followed in a majority of jurisdictions. 4 Conbin $\$ 788$; Comment, 57 Colum. L. Rev. 406, 407 (1957). It is necessary for the creation of rights in the third party that the contract clearly evidence an intent to benefit him. The benefit conferred should be direct. Id. at 408,409 .

164. 4 CORBIN $\$ 774$ defines a creditor-beneficiary as a third person having enforceable rights arising from a contract to which he is not a party and for which he gave no consideration if, "the promisee, or some other person, is under an obligation (a duty or liability) to him and the contract is so made that the promised performance or the making of the executory contract itself will discharge that obligation." See, e.g., REstatement, Contracts $\$ 133$ (1932); Comment, 57 Colun. L. Rev. 405 (1957).

Massachusetts will not allow a creditor-beneficiary of a third-party beneficiary contract a law remedy. Border v. Boardman, 157 Mass. 410, 32 N.E. 469 (1892) ; Gustafson v. Doyle, 329 Mass. 473, 109 N.E.2d 465 (1952) ; Cain's Lobster House, Inc. v. Cain, 312 Mass. 512, 45 N.E.2d 397 (1942). Connecticut and Michigan may share that position. Morgan v. Randolph \& Clowes Co., 73 Conn. 396, 47 Atl. 658 (1900) ; Edwards v. Thoman, 187 Mich. 361, 153 N.W. 806 (1915). But see Byram Lumber \& Supply Co. v. Page, 109 
despite the fact that the third party was nonexistent or not specifically designated at the time the contract was made, so long as he, or one of the class he represents, was clearly intended as beneficiary. ${ }^{105}$ Although rarely

Conn. 256, 146 Atl. 293 (1929). However, equitable relief will be granted. Baurer v. Devenis, 99 Conn. 203, 121 Atl. 566 (1923); Forbes v. Thorpe, 209 Mass. 570, 95 N.E. 955 (1911). And the promisee may recover if the beneficiary cannot do so. Dahlstron Metallic Door Co. v. Evatt Constr. Co., 256 Mass. 404, 152 N.E. 715 (1926). Moreover, the beneficiary may, by becoming an assignee of the promisee, maintain an action. Merill v. Prebilt Co., 329 Mass. 166, 107 N.E.2d 438 (1952).

So long as Miassachusetts maintains its position, a third-party beneficiary will be denied a right enforceable at law although, under the recently adopted Uniform Conmercial Code, Mass. Aws. Laws c. 107A, \$§ 1-6 (Supp. 1957), this state is now among the most liberal in permitting creation of rights in assignees. And, in an assignment, the promisor becomes bound to render to the third party the performance which he owed to the assignor, with none of the choice of terms and conditions which may be inserted by the promisor under a third-party beneficiary contract.

165. In Commodity Credit Corp. v. Henwaod, 126 F.2d 145 (8th Cir. 1942), Commodity Credit had loaned money to cotton growers, secured by warehouse receipts representing stored cotton. The lender was held liable to pay the railroad freight charges against the cotton growers for shipment to the warehouses. The court stated: "[S] uch beneficiary need not be named and need not even know the terms of the contract when executed .... It is sufficient if he comes fairly within the class or kind covered by the contract." Id. at 148. See Hamill v. Maryland Cas. Co., 209 F.2d 338 (10th Cir. 1954); Ohio Cas. Ins. Co. v. Beckwith, 74 F.2d 75 (5th Cir. 1935) (injured party could recover directly from tortfeasor's insurer) ; Capello v. Union Carbide \& Carbon Co., 200 Misc. 924, 103 N.Y.S.2d 157 (Sup. Ct. 1951) (creditor has cause of action against party who assumed the liabilities of debtor corporation); Beck v. Reynolds Metals Co., 163 F.2d 870 (7th Cir. 1947) (dictum). Levy v. Daniels' U-Drive Auto Renting Co., 108 Conn. 333, 143 Atl. 163 (1928) (beneficiary need be personally identified only at the time performance is due); Whitehead v. Burgess, 61 N.J.L. 75, 38 Atl. 802 (Sup. Ct. 1897) (same).

In contrast to the creditor-beneficiary, see note 163 supra, a mere incidental beneficiary cannot enforce an independent right. Camco Oil Corp. v. Vander Laan, 220 F.2d 897 (10th Cir. 1955) (assignee of one-fourth interest in oil lease, which was to bear its share of expenses, not liable for payment of previously incurred debt at suit of creditor).

Although the intention of the promisee alone should be controlling, courts have required that both parties intend to confer a benefit upon the third party. See Marlboro Shirt Co. v. American Dist. Tel. Co., 196 Md. 565, 77 A.2d 776 (1951), where plaintiff's lessor contracted with defendant for a sprinkler system, leakage from which ruined plaintiff's goods. Plaintiff was held to be only an incidental beneficiary; he had no independent right against defendant upon which to sue. If payment is in terms to be made to the promisee, his creditor will have difficulty proving that he was intended to be benefited directly by the contract. Camco Oil Corp. v. Vander Laan, supra; Vance v. Yonkers Contracting Co., 280 App. Div. 839, 113 N.Y.S.2d 733 (2d Dep't 1952). Since express intent to confer a direct benefit may be insisted on by the courts, a contract which is to create an enforceable right in the creditor should name him or his class as parties to be benefited, or even to receive performance. In Scarborough v. Berkshire Fine Spinning Associates, 128 F. Supp. 948 (S.D.N.Y. 1955), a bankrupt assigned a contract to a factor, to comply with the federal Assignment of Claims Act, with irrevocable instructions to pay $80 \%$ of proceeds to defendant as security for its shipment of cloth to the bankrupt, which was to manufacture handerchiefs from the cloth. The court held Berkshire a third-party beneficiary of the assignment contract between the factor and the bankrupt and awarded him the proceeds. Cf. Hamill v. Maryland Cas. Co., 209 F.2d 338 (10th Cir. 1954) 
used as a security device, due to the undesirability of notification in many financing situations, such a contract would appear adaptable to financing based on unique long-term contracts where notification is likely to be practicable. And the third-party beneficiary contract presents apparent advantages to a lender, since, rarely used, it is presently free of doctrinal limitations which encumber the assignment of contract rights. ${ }^{166}$

Under the third-party beneficiary contract, the lender's interests appear safeguarded against possible recision, modification or express repudiation by the immediate parties. At least after the creditor has acted in reliance, the ability to modify or rescind without his consent is destroyed. ${ }^{\mathbf{1 6 7}}$ Where a lender utilizes a third-party beneficiary contract as security, the loan itself should be sufficient reliance to insure his status. ${ }^{168}$ Moreover, some precedent

(company which issued performance bond in reliance on Hamill's promise to the contractor to advance $10 \%$ of expenses of construction contract entitled to recover from Hamill despite the fact that it was not an express beneficiary) ; Reeves v. Better Taste Popcorn Co., 246 Iowa 508, 66 N.W.2d 853 (1955) (agreement for the purchase of popcorn from tenant, consented to and signed by landlord, held to create an enforceable right in the landlord, as third-party beneficiary, against the purchaser for share of the crop which had been agreed on, with tenant, as rent).

166. Benedict v. Ratner, 268 U.S. 353 (1925), see notes 119-26 supra and accompanying text, has never been applied to a third-party beneficiary contract. The broad interpretation of that doctrine, explained at note 127 supra, would be inapplicable to third-party beneficiary contracts since the parties cannot alter the beneficiary's rights once he has relied upon the contract. See note 168 infra; Comment, 57 ColuM. L. Rev. 406, 414-18 (1957). And since the loan could be made concurrent with or subsequent to the contract, or expressly in reliance upon its formation as part of the transaction, the lender's rights would be fixed.

The contract would not be preferential if the right granted the creditor-beneficiary is created concurrent with or prior to the loan since the transfer would be perfected as of the date of contract or as of the date of reliance shown by the making of the loan; in neither case would it be for an antecedent debt under $\$ 60$ (a) (2) of the Bankruptcy Act, 64 STAT. 25 (1950), 11 U.S.C. $\$ 96(a)(2)$ (1952). Thus, even if the loan were made within four months of bankruptcy, the lender's right would be valid so long as fair consideration were given and no actual intent to hinder and delay creditors existed. Bankruptcy Act $\S$ 67 (d), 52 Stat. 877 (1938), as amended, 11 U.S.C. $\$ 107$ (d) (1952); UNIForm FrauduLeNT Conveyance ACT $\$ 7$.

167. 4 Corbin $\S 815$ bases this result upon principles of estoppel. See Page, The Power of the Contracting Parties To Alter a Contract for Rendering Perfornance to a Third Person, 12 WIS. L. REv. 141 (1937), for criticism of cases which delay the vesting of the creditor-beneficiary's rights until action in reliance. The article compares the development of this body of law to the law of assignments for security.

168. Fourteen states by statute or case law hold that parties to a contract may rescind it or alter the rights of the beneficiary under it only before it has been accepted, adopted or acted upon by a third-party beneficiary. CAL. CIv. CODE $\$ 1559$, Riley v. Riley, 118 Cal. App. 2d 11, 256 P.2d 1056 (1953); IdAgo Code ANN. \$ 29-102 (Supp. 1957); Mont. Rev. Codes ANn. \$13-204 (Supp. 1957) ; N.D. Rev. Code \$ 9-0204 (1943), Klein v. Klein, 69 N.D. 353, 286 N.W. 898 (1939); Okza Stat. Avs. tit. 15, \& 29 (Supp. 1957); S.D. Cone $\$ 10.0204$ (Supp. 1952). See also LA. Civ. Cone Ann. art. 1890 (West 1952) ; GA. Code Ann. \$ 3-108 (Supp. 1955) ; N.J. Rev. Stat. § 2:26-3.6 (1937); VA. CODE ANN. $\$ 55-22$ (Supp. 1956), which state that a person for whose benefit a contract is made may sue thereon. Michigan is in general agreement. MIck. Coxp. LAws §§ 
exists for protection of a creditor-beneficiary even in the absence of detrimental reliance. Thus, the making of a contract has been ruled to fix a creditor's rights. ${ }^{109}$ Other cases, and statutes as well, hold the creditor's acceptance of the terms of a contract determinative. ${ }^{170}$ In the financing context, acceptance may be implied when the contract is made or when the lender has knowledge of its execution. Then, only failure of performance by the borrower would upset the security. ${ }^{171}$ While even this eventuality could be countered by drawing the contract so that the obligor's duty to the third-party beneficiary was independent of the borrower's performance, ${ }^{172}$ an obligor is unlikely to agree to so onerous an undertaking. Such an agreement, however, would also eliminate the perils of the borrower's bankruptcy, since rejection of the contract by the trustee would not destroy the lender's independent right against the obligor. Although less satisfactory, an option to assume and delegate performance might be included in the contract, to be asserted by the beneficiary against the obligor and the trustee in bankruptcy. ${ }^{173}$ In any event, the beneficiary will always be entitled to all payments falling due prior to bankruptcy. ${ }^{174}$

691.541-.542 (1948). Colorado, Starbird v. Cranston, 24 Colo. 20, 48 Pac. 652 (1897); Illinois, Bay v. Williams, 112 Ill. 91, 1 N.E. 340 (1884); Plily v. Phifer, 1 I1l. App. 2d 398, 117 N.E.2d 678 (1954) ; and Wisconsin, Tweeddale v. Tweeddale, 116 Wis. 517, 93 N.W. 440 (1903); In re Bratt, 257 Wis. 447, 43 N.W.2d 817 (1950), hold by case law that a third-party beneficiary's rights vest immediately upon formation of the contract. See, e.g., Comment, 57 Colum. L. Rev. 406, 414, 419-20 (1957). 4 Corbin $\$ 815$ nn.62 \& 63 lists Alabama, Arkansas, Indiana, Iowa, Kentucky, Maine, Minnesota, New York, New Mexico, Ohio, Oregon, Rhode Island, South Carolina, Texas, Utah and Washington as additional states adhering by case law to the proposition that the promisee's power to discharge the promisor no longer exists after the third-party creditor-beneficiary assents or acts in reliance on the contract. See also American Trust Co. v. Catawba Sales \& Processing Co., 242 N.C. 370, 88 S.E.2d 233 (1955).

Thus, in a majority of states, and probably in all those recognizing the third-party beneficiary concept, see note 163 supra, the creditor-beneficiary's rights will be fixed, at the latest, at the time he assents to or relies upon the contract by making the loan.

169. Tweeddale v. Tweeddale, supra note 168; Starbird v. Cranston, supra note 168; Bay v. Williams, supra note 168 ; Pliley v. Phifer, supra note 168.

170. See note 168 supra.

171. 4 CORBIN $\$ 816$.

Since the beneficiary's right is only as good as the contract it is founded upon, the security would, of course, also be destroyed if the contract were fraudulent, entered into through mutual mistake or otherwise voidable. See Rouse v. United States, 215 F.2d 872 (D.C. Cir. 1954) (fraud of vendor entitled vendee to set up defense against plaintiff beneficiary of contract); Restatearent, Contracts $\$ 140$ (1932).

172. The parties to the contract being free to delimit their contractual relations, it would be possible for the promisor's obligation of performance to the third-party beneficiary to be made independent of the borrower's performance under the contract. 1 Corbin $\$ \$ 125,152 ; 3$ Williston, Contracts $\$ 858$ (rev. ed. 1936). Such a construction of the contract by the courts, however, would be unlikely.

173. See notes 72-73 supra and accompanying text.

174. Scarborough v. Berkshire Fine Spinning Associates, 128 F. Supp. 948 (S.D.N.Y. 1955) ; Pliley v. Phifer, 1 Ill. App. 2d 398, 117 N.E.2d 678 (1954) (third-party beneficiary's rights superior to the promisee's subsequent judgment creditors).

Nevertheless, rejection of the underlying contract would destroy the third-party beneficiary's rights, which are dependent upon it. See note 155 supra. If the trustee in 
More significantly, the third-party beneficiary technique would apparently be free of all the formalities of perfection, ${ }^{175}$ recordation ${ }^{176}$ and supervision ${ }^{177}$ which may plague assignment financing. Thus, the creditor beneficiary's rights would be perfected both in and out of bankruptcy as soon as his loan was made. No further act such as recordation would be required. Nor would any form of notice to creditors be necessary. If the loan were made concurrently with or subsequent to the formulation of the contract, and constituted fair value, no possibility of invalidation as a preferential or fraudulent transfer would exist. ${ }^{178}$ And since the beneficiary's interest would spring directly from the contract, his collection of proceeds only under specified conditions-notification of intent to call in the security, for example ${ }^{179}$-would be entirely permissible. Allowing the borrower to collect proceeds of the contract until otherwise directed by the lender would, accordingly, not impair the security as would lack of supervision of an assignment under Benedict.

Nevertheless, the third-party beneficiary contract will most likely be unavailable as a security device. Should the courts accept this arrangement as an independent security instrument, they would probably surround it with limitations analogous to those found in assignment law. More likely, they would assimilate it directly to an assignment and not allow mere nomenclature to modify legal results when the parties and their interests are identical. Since the third-party beneficiary contract does not furnish the minimum safeguards advocated for security techniques-serving a notice and an evidentiary function ${ }^{180}$ — such a result would be justifiable.

\section{ConcLusion}

A relatively unused type of financing, lending upon the security of longterm contract rights should take the form of assignment transactions. The third-party beneficiary contract approach, while indicating the anachronism of present assignment formalities, is open to uncertain treatment at the offices of the courts. Frequently, Iong-term contracts will be assignable according to statutory provisions established for accounts receivable. Elsewhere, common-law doctrines must be observed. Whatever the jurisdiction, care must be taken to conform to the manifold technical requirements necessary to creation and maintenance of a secured interest. With such precautions, long-term contract rights should be readily available as a source of security, invalidation possibilities restricted to actual fraud and failure of consideration.

bankruptcy assumed the contract, the third party would also be entitled to all performances due under the contract after bankruptcy. See note 158 supra.

175. Compare notes 46, 47 supra and accompanying text, with notes 167, 163 supra.

176. See notes $92-98$ supra.

177. See notes 125,131 supra.

178. Cf. note 143 supra.

179. 4 CORBIN $\$ 817$. Such an arrangement would be analogous to the valid conditional assignment. See notes 140, 141 sipra. Since the creditor-beneficiary is given limited rights under the contract, no conceptual repugnancy between a purported transaction and actual conduct would exist.

180. See text at notes $84-89$ supra. 